J. Dairy Sci. 98:6029-6047

http://dx.doi.org/10.3168/jds.2014-8749

(C) 2015, THE AUTHORS. Published by FASS and Elsevier Inc. on behalf

of the American Dairy Science Association ${ }^{\circledR}$. This is an open access article under

the CC BY-NC-ND license (http://creativecommons.org/licenses/by-nc-nd/3.0/).

\title{
An investigation of the dynamics of intramammary infections acquired during the dry period on European dairy farms
}

\author{
A. J. Bradley, ${ }^{*}{ }^{1}$ S. De Vliegher, $\ddagger$ M. J. Green, $\dagger$ P. Larrosa,§ B. Payne, ${ }^{*}$ E. Schmitt van de Leemput,\# \\ O. Samson,II D. Valckenier,ł T. Van Werven, $\|^{* *}$ H. W. F. Waldeck, ${ }^{* *}$ V. White, ${ }^{*}$ and L. Goby†† \\ *Quality Milk Management Services Ltd., Cedar Barn, Easton Hill, Easton, Nr Wells, Somerset, BA5 1DU, United Kingdom \\ †School of Veterinary Medicine and Science, Sutton Bonington Campus, University of Nottingham, Sutton Bonington, Leicestershire, LE12 5RD, \\ United Kingdom \\ $\ddagger$ M-team and Mastitis and Milk Quality Research Unit, Department of Reproduction, Obstetrics, and Herd Health, Faculty of Veterinary Medicine \\ Ghent University, 9820 Merelbeke, Belgium \\ §El Barranquillo SL, Calle Las Tenadas S/N, 30700 Torre Pacheco, Murcia, Spain \\ \#Clinique Veterinaire, Vetformance, 1 Rue Pasteur, 53700 Villaines La Juhel, France \\ ॥Clinique Veterinaire, Vetformance, 39 Rue Jules Ferry, 53100 Mayenne, France \\ IFaculty of Veterinary Medicine, Department of Farm Animal Health, Utrecht University, Yalelaan 7, Utrecht 3584 CL, the Netherlands \\ **University Farm Animal Practice, Reijerscopse Overgang 1, Harmelen 3481 LZ, the Netherlands \\ ††Boehringer Ingelheim Animal Health $\mathrm{GmbH}$, Binger Strasse 173, 55216 Ingelheim am Rhein, Germany
}

\begin{abstract}
The dry period is acknowledged as playing a key role in mastitis epidemiology and yet surprisingly few studies have explored dry period infection dynamics in detail. The aim of this study was to investigate the dynamics of intramammary infection across a cohort of dairy herds in Europe. Five hundred and twentytwo cows were recruited from 12 farms in 6 European countries. All cows received antibiotic dry cow therapy but teat sealants were not used. All quarters of all cows were sampled for bacteriology at drying off and in the week immediately postcalving. Two ipsilateral quarters were also sampled for bacteriology in each cow 2 and 6 wk after drying off. Cows were body condition scored and teats assessed for cleanliness at all sampling time points and for the presence of a keratin plug during the dry period. Other cow-level parameters such as historic somatic cell counts and milk yields before drying off were collated from farm records. Univariable and multivariable analyses were undertaken to investigate the etiology, prevalence, and dynamics of infection during the dry period and associated influential factors. In summary, environmental mastitis pathogens predominated. Although gram-positive major pathogens were typically well controlled and did not increase in prevalence across the dry period, gram-negative pathogens generally increased in prevalence. There was an in-
\end{abstract}

Received August 16, 2014.

Accepted April 18, 2015.

${ }^{1}$ Corresponding author: andrew.bradley@qmms.co.uk crease in the number of quarters that yielded no growth across the dry period, although this was driven by minor rather than major mastitis pathogen control. Other than the presence of a gram-positive or gram-negative pathogen 6 wk after drying off, the measured parameters were not influential when considering their effect on the presence of pathogens postcalving. Analysis also suggested that the early and mid dry period may be more important with respect to the timing of acquisition of infection than previously thought. We observed substantial variation in the etiology and prevalence of different pathogens on different farms with, in all cases, at least one of the 12 herds experiencing the opposite of the others with respect to increases and decreases in pathogen prevalence. Overall, this study confirms the importance of the dry period in mastitis epidemiology but highlights the importance of assessing and understanding infection dynamics on individual units. The lack of influence of the cow and quarter factors measured in this study suggests that herd and management factors may be more influential.

Key words: mastitis, dry period, intramammary infection

\section{INTRODUCTION}

The importance of the nonlactating period in mastitis epidemiology has been recognized for many years, and the need to control IMI at this time is reflected in the historical importance and emphasis placed on the use of antibiotic dry cow therapy (Bradley and Green, 2004). However, a relatively small number of studies have attempted to investigate the detailed dynamics of 
IMI during the dry period. Smith et al. (1985) and Todhunter et al. (1991) described the importance of the dry period and infection during the dry period in an Ohio dairy herd, with a particular emphasis on environmental mastitis pathogens. Similar work was undertaken in a small cohort of dairy herds in Somerset in the UK in the late 1990s (Bradley and Green, 2000) when a link was more definitively established between infection in the dry period and subsequent clinical mastitis (Green et al., 2002). Further research defined some risk factors but was limited by those parameters measured at the time of the original research (Green et al., 2007).

Although the importance of the dry period is acknowledged and a large number of clinical trials have investigated the use of antibiotics (Robert et al., 2006) and teat sealants (Rabiee and Lean, 2013), there is a relative dearth of studies investigating factors influencing the likelihood of infection during the dry period, with studies instead tending to focus on lactation. The growing concern about antimicrobial resistance has led to increased scrutiny of antibiotic use in agriculture. Despite the importance of the dry period in mastitis epidemiology, the blanket use of antibiotic dry cow therapy is being challenged because its use is primarily prophylactic in many cows. To successfully manage this challenge, we need a better understanding of the risk factors associated with infection during the dry period so that we can improve or at least maintain levels of control in the face of reduced antibiotic use.

Cow- and quarter-level risk factors associated with the risk of IMI have included, among others, breed (Brolund, 1985; Elbers et al., 1998), parity, yield at drying off (Huxley et al., 2002; Dingwell et al., 2004), dry period length, cow and udder hygiene (Schreiner and Ruegg, 2003), teat end callosity (Breen et al., 2009a,b), negative energy balance (Suriyasathaporn et al., 2000), and SCC history and pathogen interaction in the gland (Green et al., 2005), although there is not universal agreement on the relative or absolute importance of many of these factors or their role during the dry period.

Previous research has investigated the importance of herd-level management factors across a large number of herds in the UK on dry period outcomes and has highlighted the importance of herd-level factors such as environmental management, proactive BCS management, and dry cow therapy selection among others (Green et al., 2007, 2008).

Despite the importance of the dry period, only a small number of studies have investigated the dynamics of IMI during the dry period by sampling during the dry period and these have not attempted to proactively investigate the effects of cow and quarter risk factors on dry period outcomes. The aim of this study was to describe the prevalence and etiology of IMI, in the nonlactating period, in a large cohort of cows, across several farms across different jurisdictions in Europe while collating cow- and quarter-level information to facilitate an investigation of cow- and quarter-level factors influencing dry period outcomes.

\section{MATERIALS AND METHODS}

\section{Herd and Cow Selection}

A convenience sample of 12 herds was selected from 6 European countries (Belgium, France, Poland, Spain, the Netherlands, and the United Kingdom) with the aim of recruiting approximately 100 cows in each jurisdiction over a 12-mo period. Herds were selected on the basis of relatively low bulk milk SCC, a willingness to comply with the study protocol, and no fixed strategy for the allocation of herd management numbers. Although herds that did not use an internal teat sealant were selected, no restrictions were placed on dry cow therapy selection. All cows within each herd were eligible for enrollment in the study. In large herds, 2 cows were randomly selected for inclusion in the study each week to ensure year-round recruitment. A standard operating procedure, devised before the study, was used to randomly select cows. In summary, this involved selecting one even- and one odd-numbered cow (based on management code) on each farm; where more than one eligible cow was present, lots were drawn from a cloth bag.

\section{Study Protocol}

Before commencement of the study, the key members of the research team met to discuss the study protocol and to agree and standardize the standard operating procedures to be used. Although it was not possible to perform on-farm training of investigators for cost and logistical reasons, it was agreed that country-specific practices would be ignored and the standard operating procedures followed. All sampling and scoring was undertaken by the authors or personnel who were present at the prestudy meeting.

Sampling Strategy. Duplicate quarter lacteal secretion samples were collected, by the authors, from all 4 quarters at drying off and during the week immediately postcalving. During the dry period, duplicate samples were taken from 2 ipsilateral quarters [left fore $(\mathbf{L F})$ and left hind $(\mathbf{L H})$ odd-numbered cows or right fore (RF) and right hind (RH) even-numbered cows] 2 and 6 wk after drying off (assuming the cow had not calved). 
Two quarters remained unsampled as controls to assess whether the sampling procedure was associated with an increase in the risk of acquisition of new IMI.

Sampling Procedure. Teats were initially wiped to remove gross contamination before being dipped in a solution containing $2,800 \mathrm{mg} / \mathrm{L}$ available chlorine (Presept or equivalent; Johnson \& Johnson Ltd., Ascot, UK). Following a minimum 30-s contact time, the teats were wiped dry. Each teat was subsequently scrubbed with a cotton wool swab soaked in $70 \%$ ethanol and allowed to dry. Before collection of the first sample, the teat ends were scrubbed for a second time using $70 \%$ ethanol and foremilk was discarded (except from udders assessed as having little secretion present during the dry period, when foremilk was collected). Following a third scrub of the teat ends, duplicate samples were collected. After sampling, teats were dipped in a solution containing $2,800 \mathrm{mg} / \mathrm{L}$ of available chlorine and cows were confined to a loafing yard for at least $30 \mathrm{~min}$. Disposable gloves were worn throughout the sampling process and changed between cows.

Dry Cow Therapy Infusion. Dry cow therapy was infused by, or under the supervision of, study personnel immediately following the sampling before drying off. Administration was according to manufacturer guidelines and, by virtue of the sampling technique, would typically have followed the predipping and 3 scrubs with $70 \%$ ethanol (detailed above).

Sample Storage and Shipment. Immediately following collection, all samples were stored in a cool box and maintained at or below $8^{\circ} \mathrm{C}$. Samples were typically shipped so they would reach the testing laboratory within $48 \mathrm{~h}$. If immediate shipment was not possible, then samples were frozen $\left(\right.$ at $\left.-20^{\circ} \mathrm{C}\right)$ until shipment. Before the start of the study, the shipment containers and protocol were tested and were demonstrated to maintain samples below $5^{\circ} \mathrm{C}$ for at least $72 \mathrm{~h}$.

Assessment of Teat Closure. The degree of teat closure was assessed, before sampling, in teats sampled during the dry period and scored on a scale of 1 to 3 as outlined below. Score 1: secretion appears at the teat end following application of little or no pressure; score 2: secretion does not appear immediately at the teat end following gentle application of pressure; when secretion does appear, it is not accompanied by an obvious release of pressure and displacement of a keratin plug; score 3: very significant pressure has to be applied to obtain secretion from the gland, when secretion is obtained, there is an obvious release of pressure and a keratin plug may be obvious in the sample. Teats scoring 2 or 3 were defined as closed.

Assessment of Teat Cleanliness. Teats were assessed before sampling for the absence or presence of organic matter and scored on a scale from 1 to 3 as outlined below. Score 1: no organic matter visible and teats appear visually very clean; score 2 : some organic matter is present, but $<20 \%$ of the teat surface is soiled and the teat end is not affected; score 3: soiling is present with $>20 \%$ of the teat surface, the teat end, or both, being affected.

Assessment of BCS. Body condition score was assessed on a scale of 1 to 5 (half points were allowed), using the method described by Wildman et al. (1982), at each sampling time point.

\section{Laboratory Procedures}

All laboratory testing was performed at a single laboratory (Quality Milk Management Services Ltd., Somerset, UK). Microbiological investigation and SCC were carried out using standard milk sample examination techniques, which exceeded the standard recommended by the International Dairy Federation (Bulletin No 132, 1981), International Standard 13366-1:1997 (E) and 13366-2:1997 (G) (International Dairy Federation, 1981). A more complete description of these techniques is outlined below.

Bacteriology. Ten microliters of secretion was inoculated onto sheep blood agar and Edward's agar; $100 \mu \mathrm{L}$ of secretion was inoculated onto MacConkey agar to enhance the detection of Enterobacteriaceae. Plates were incubated at $37^{\circ} \mathrm{C}$ and read at 24,48 , and $72 \mathrm{~h}$. Organisms were identified and quantified using standard laboratory techniques (Quinn et al., 1994; National Mastitis Council, 1999) and matrix-assisted laser desorption/ionization time-of-flight (MALDI-TOF) MS (MALDI Biotyper, Bruker Daltonics, Bremen, Germany).

The MALDI-TOF MS was the primary method used to identify organisms. Individual colonies, selected for the purposes of identification, were applied to a steel plate (Bruker Daltonics) and allowed to dry at room temperature before being overlaid with $1 \mu \mathrm{L}$ of MALDI Matrix [a saturated solution of $\alpha$-cyano-4hydroxycinnamic acid (Bruker Daltonics) in 50\% acetonitrile and $2.5 \%$ trifluoroacetic acid]. Spectra were generated using the manufacturer's suggested settings and were captured and analyzed using the flexControl and MALDI Biotyper 3.0 software (Bruker Daltonics). Ions were generated with a $337-\mathrm{nm}$ nitrogen laser and captured in the positive linear mode in a mass range of 2 to $20 \mathrm{kDa}$. Spectra were compared with a database containing in excess of 3,500 spectra from over 2,000 bacterial species. Each plate also carried a standard (Bacterial Test Standard, Bruker Daltonics) to calibrate the instrument and validate each run. Organisms were 
identified using criteria outlined by the manufacturer; this method uses an integrated pattern-matching algorithm to match spectral peaks against known bacterial species before assigning a log sore against a maximum value of 3.0. For the purposes of this study, identifications were only accepted where a score in excess of 2.0 was achieved and a "probable" species-level identification applied that was also consistent with colonial and organism morphological characteristics. In the very small number of cases $(\mathrm{n}=71)$ where a species-level identification could not be achieved, conventional biochemical techniques were used, such as API (bioMérieux, Basingstoke, UK).

Somatic Cell Counting. Somatic cell counts were determined using the Fossomatic method (Delta CombiScope, model FTIR 400, Drachten, the Netherlands), according to FIL-IDF 148 A: 95 norm (International Dairy Federation, 1995).

\section{Definition of Terms Used for Analysis}

Infection dynamics of the mammary gland were explored following the principles outlined below. For the purposes of exploration of infection dynamics, only complete quarter data sets without any "contaminated" diagnoses were included in the analysis.

Intramammary "Infection" Status. Isolation of an organism was taken to be indicative of an IMI, giving a theoretical limit of detection of $10 \mathrm{cfu} / \mathrm{mL}$ of coliforms and Staphylococcus spp. and $100 \mathrm{cfu} / \mathrm{mL}$ of other organisms based on the inoculum volumes outlined earlier. A sample was considered contaminated if more than 3 pathogens were cultured from a sample. If this occurred, then the duplicate sample was submitted for bacteriological analysis (Bradley and Green, 2000). If the duplicate sample was deemed contaminated, that quarter was excluded from the analysis of infection dynamics as described above. Several outcomes were assessed, as outlined below.

Cure of Existing IMI. A cure was defined as the absence of a pathogen in a quarter sample that had been present at the previous sampling time point in that quarter.

Acquisition of New IMI. A new infection was defined as the presence of a pathogen in a quarter sample that had not been present at the previous sampling time point in that quarter. Therefore, a quarter infected with one pathogen at a given time point was eligible to acquire a new infection with a different pathogen by the subsequent time point.

Successful Dry Period Outcome. A successful outcome was defined in 2 ways; first, as the absence of a major pathogen from the postcalving sample and, second, as the absence of any mastitis pathogen (major or minor) from the postcalving sample.

Teat Closure. A teat was considered closed when scoring $>1$ using the method outlined above.

\section{Data Collation and Statistical Analyses}

Data were collated and initially analyzed using Excel and Access 2003 (Microsoft Corp., Redmond, WA) and Minitab 15.1 (Minitab Inc., State College, PA). Descriptive and graphical analyses were carried out to explore the data. Where appropriate, groups were compared using the Kruskal-Wallis test or ANOVA. The $\chi^{2}$ test was used to investigate differences in proportions. A layered Bonferroni correction was used to allow for multiple comparisons where appropriate (Darlington, 1990).

The overall aim of the statistical modeling was to evaluate the effect of possible explanatory factors on the risk of IMI during the dry period and postcalving. Conventional multilevel (random effects) models (Goldstein, 1995) were specified so that correlations within the data were accounted for appropriately. For the purposes of these models and because only a very small number of cows were recruited on some farms, farms were grouped by country, and the term "country" was included as a fixed effect to account for systematic differences between countries. General model specifications (for the binary outcomes) were

$$
\begin{gathered}
\mathrm{Y}_{\mathrm{ij}} \sim \text { Bernoulli }\left(\text { probability }=\pi_{\mathrm{ij}}\right), \\
\operatorname{Logit}\left(\pi_{\mathrm{ij}}\right)=\alpha+\beta 1 \mathbf{X}_{\mathrm{ij}}+\beta 2 \mathbf{X}_{\mathrm{j}}+\mathrm{u}_{\mathrm{j}}, \\
\mathrm{u}_{\mathrm{j}} \sim \mathrm{N}\left(0, \sigma_{\mathrm{u}}^{2}\right),
\end{gathered}
$$

where $\mathrm{Y}$ is the occurrence of IMI (in either the dry period or postcalving), subscripts $\mathrm{i}$ and $\mathrm{j}$ denote the ith quarter and the jth cow, respectively, $\alpha$ is the regression intercept, $\mathbf{X}_{\mathrm{ij}}$ is the vector of covariates at the quarter level, $\beta 1$ the coefficients for covariates $\mathbf{X}_{\mathrm{ij}}, \mathbf{X}_{\mathrm{j}}$ is the vector of cow-level covariates, $\beta 2$ the coefficients for covariates $X_{j}$, and $u_{j}$ the random effect to reflect residual variation between cows, and $u_{j}$ the random effect to reflect residual variation between cows with mean $=0$ and variance $\sigma_{\mathrm{u}}^{2}$. Covariates tested in the models were country, season of drying off (winter, spring, summer, autumn), parity, cow milk yield before drying off, BCS and BCS change, cow SCC before drying off, dry period length, dry cow therapy product administered, quarter IMI status at different times during the dry period, quarter position ( $\mathrm{LH}, \mathrm{RH}, \mathrm{LF}, \mathrm{RF}$ ), and a score given for teat hygiene and teat orifice openness. 
Table 1. Key aspects of predominant dry cow accommodation in herds recruited to the study

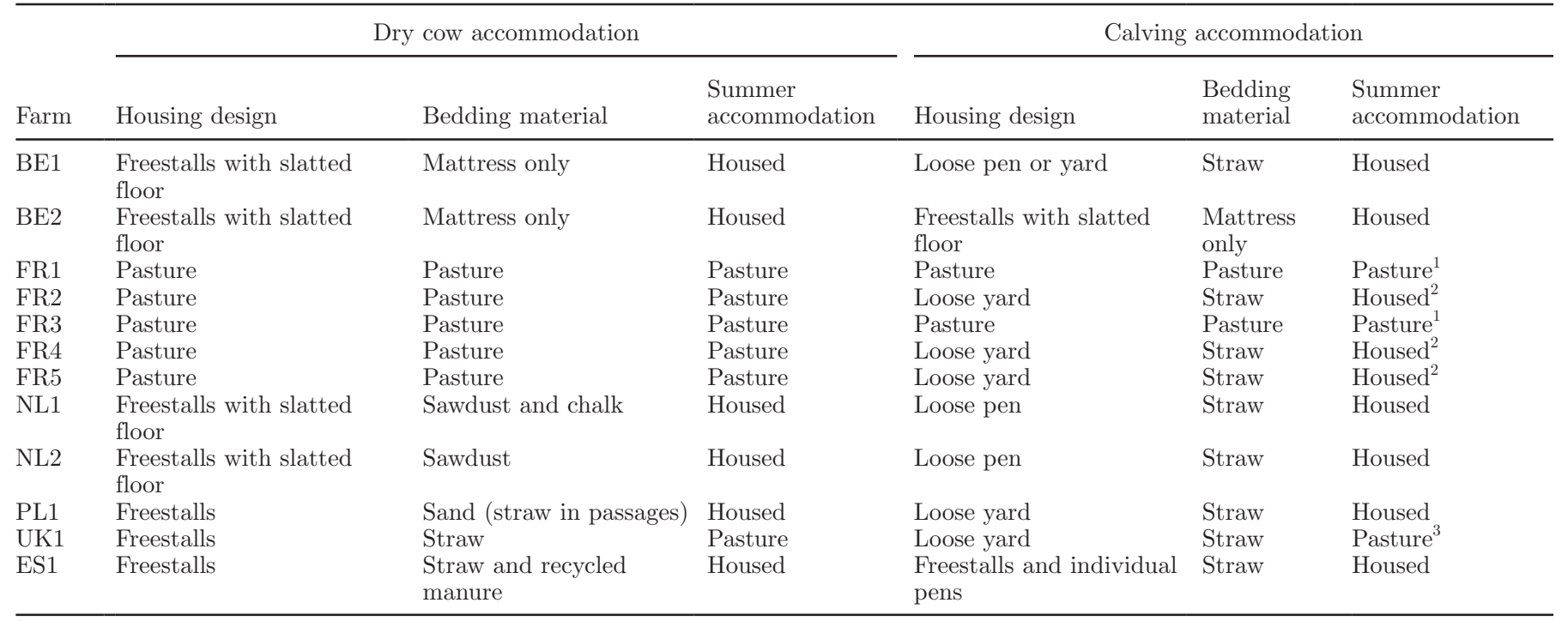

${ }^{1}$ Problem cows and heifers calved in straw yard.

${ }^{2}$ Occasional cows calve at pasture.

${ }^{3}$ Occasional problem cows calve indoors.

Covariate assessment and selection was carried out using MLwiN with MQL or PQL for parameter estimation (Rasbash et al., 2005). A significance probability was set at $P<0.05$. Investigation of model fit was using standard methods as previously described (Goldstein, 1995; Green et al., 2004).

\section{RESULTS}

A total of 522 cows were recruited, of which 454 were available for analysis, from 12 farms across 6 European countries between July 2011 and December 2012. The actual number of cows recruited and number available for analysis fell short in several countries for a variety of reasons, including logistical difficulties with transport, contaminated samples, fertility issues resulting in lower than anticipated recruitment rates, and other health issues. Farm systems and dry cow management systems were diverse, encompassing pasture-based and housed environments (including loose-housed and freestall systems, free access and TMR systems with seasonal variation in management both between and within farms); key aspects of the environmental management of the recruited herds are summarized in Table 1. Between 18 and 106 cows were recruited per farm, salient details of which are outlined in Table 1. The predominant breed was Holstein Friesian with the exception of herd FR1, which was Normande. A diverse range of antibiotic dry cow therapies were used on the different farms, as outlined in Table 2; these encompassed first- and fourth-generation cephalosporins, penicillins, and aminoglycosides, with up to 3 different therapies used in different cows within the same herd. Dry periods varied in length from only $5 \mathrm{~d}$ to as long as $189 \mathrm{~d}$, but averaged $58 \mathrm{~d}$ long. Yields before drying off varied between 1 and $35 \mathrm{~L}$. Although the average yield at drying off was $14 \mathrm{~L}$, it varied between 6.9 and $23.2 \mathrm{~L}$ on different farms. The median SCC of cows recruited to the study was 116,000 cells/mL; however, the median individual cow SCC of cows recruited in the UK herd was $>300,000$ cells $/ \mathrm{mL}$. Although the calculated SCC of the UK herd had been below 250,000 cells/mL before the commencement of the study, it increased during the 18 mo of the study in part due to the retention of older cows as the herd expanded.

Body condition scores were collated from 448, 417, 307, and 403 cows at drying off, 2 and 6 wk later, and immediately postcalving, respectively. The change in BCS across the dry period was assessed in 398 cows. The proportion of cows with a target BCS of between 2.5 and 3.5 is summarized in Table 3. As expected, there was considerable variation in BCS between the farms, both at any given point during the dry period and with respect to BCS gain or loss across the dry period. Overall, 31.7 and $23.7 \%$ of cows lost or gained condition, respectively, during the dry period; individual farm details are outlined in Figure 1.

The cleanliness of teats was assessed in 503, 495, 438, and 462 cows at drying off, 2 and 6 wk later, and immediately postcalving, respectively. There was 


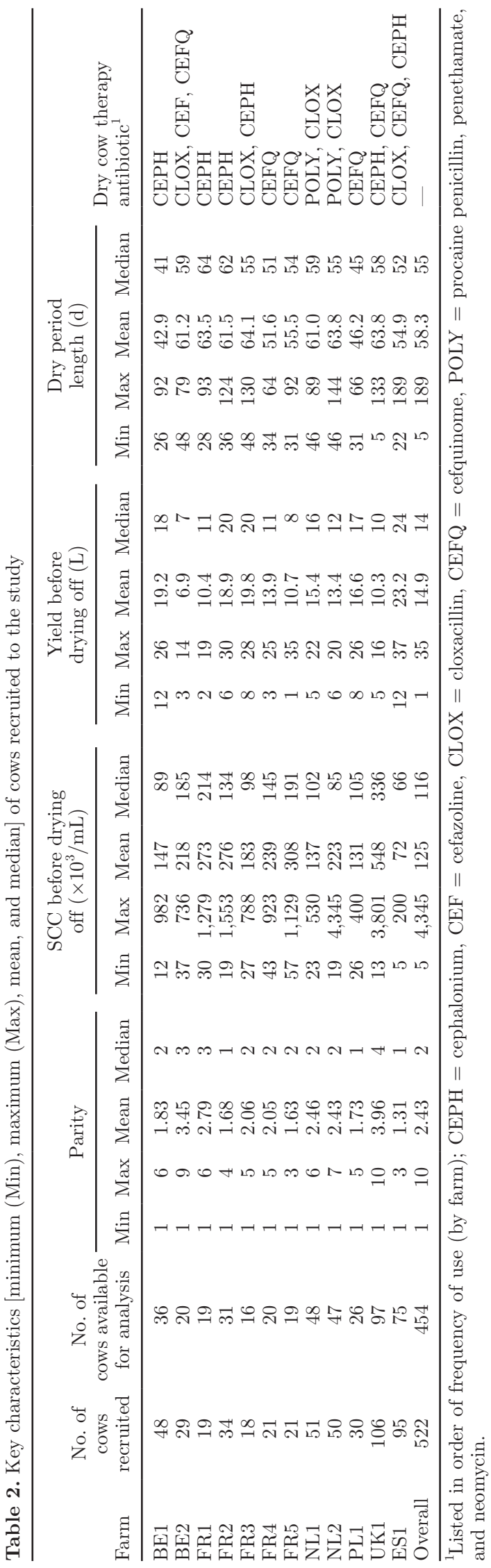

Table 3. Percentage of cows with a BCS of between 2.5 and 3.5 at each of the sampling time points

\begin{tabular}{lcccc}
\hline Farm & $\begin{array}{c}\text { Dry } \\
\text { off }\end{array}$ & $\begin{array}{c}2 \text { wk } \\
\text { after } \\
\text { dry off }\end{array}$ & $\begin{array}{c}6 \text { wk } \\
\text { after } \\
\text { dry off }\end{array}$ & Postcalving \\
\hline No. of cows & 443 & 417 & 307 & 403 \\
BE1 & 97.2 & 100 & 91.3 & 90.9 \\
BE2 & 78.9 & 94.1 & 86.7 & 83.3 \\
FR1 & 52.6 & 25.0 & 26.7 & 41.2 \\
FR2 & 74.2 & 62.1 & 68.2 & 84.6 \\
FR3 & 81.3 & 73.3 & 84.6 & 93.3 \\
FR4 & 40.0 & 65.0 & 38.9 & 47.4 \\
FR5 & 36.8 & 41.2 & 64.3 & 77.8 \\
NL1 & 95.8 & 89.1 & 95.5 & 93.3 \\
NL2 & 91.5 & 93.2 & 97.0 & 94.7 \\
PL1 & 100 & 100 & 100 & 100 \\
UK1 & 73.7 & 72.3 & 68.2 & 75.8 \\
ES1 & 58.3 & 66.7 & 80.7 & 90.6 \\
Overall & 75.4 & 75.1 & 77.9 & 83.1 \\
\hline
\end{tabular}

substantial variation in the cleanliness of teats between farms at all time points as illustrated in Figure 2. The overall proportion of teats defined as clean (score 1) was significantly $(P<0.001)$ different between all of the scoring time points with $67.4,43.1,50.8$, and $58.7 \%$ of teats being defined as clean at drying off, 2 and $6 \mathrm{wk}$ later, and immediately postcalving, respectively.

The degree of teat closure was assessed in 495 and 432 cows 2 and 6 wk after drying off, respectively, and is illustrated in Figure 3. The proportion of teats defined as closed on farms varied between 35.7 and $73.5 \%$ 2 wk after drying off and between 11.1 and $97.1 \%$ at 6 wk after drying off. Overall, significantly more teats were defined as closed $(P<0.001)$ at 6 wk than at 2 wk after drying off.

The findings of bacteriological analysis of samples collected at each of the sampling time points are summarized in Table 4. Among the major mastitis pathogens, we detected a significant decrease in the prevalence of Streptococcus uberis-infected quarters between drying off and 2 wk after drying off, although by 6 wk after drying off, this decrease was lost. Similarly, there was a significantly higher prevalence of quarters infected with Staphylococcus aureus at drying off than at any of the other sampling time points. We detected no other significant differences in prevalence across the sampling time points with any other major pathogens at the species-specific level. However, we detected a higher prevalence of coliform and gram-negative-infected quarters at 6 wk after drying off and postcalving compared with at drying off, and a higher prevalence of gram-positive-infected quarters at drying off than at other sampling time points. There were significant changes in the prevalence of infection with the minor mastitis pathogens. An initial significant decrease in the prevalence of CNS between drying off and 2 wk 


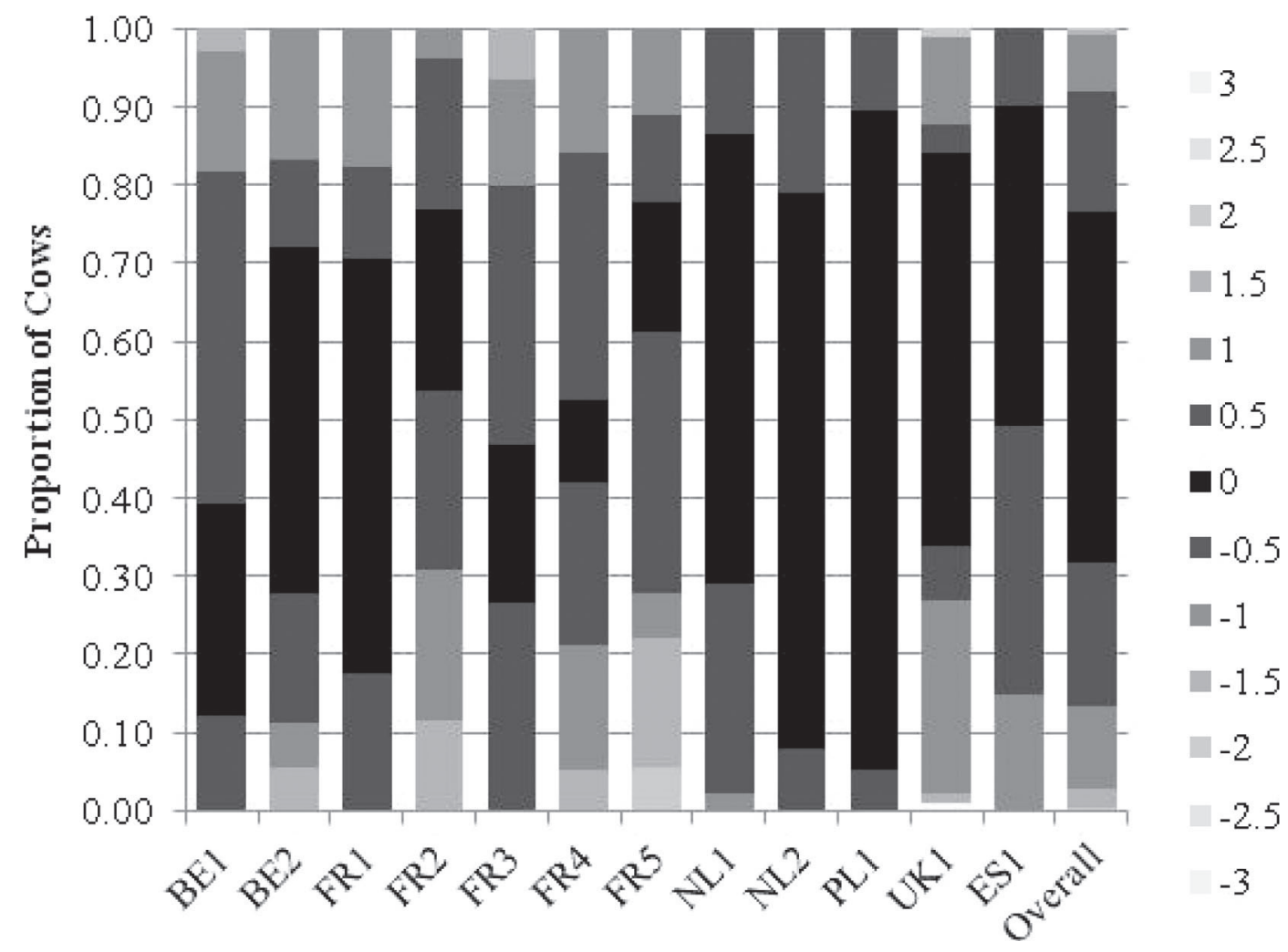

Figure 1. An illustration of change in BCS across the dry period in the 12 study farms.

postcalving was followed by a significant increase in the prevalence between 2 and 6 wk after drying off and a subsequent decrease in prevalence postcalving to a level significantly lower than that seen at drying off. We detected a significant decrease in the prevalence of Corynebacterium spp. between drying off and $2 \mathrm{wk}$ after drying off, although the prevalence increased significantly by the postcalving sample, albeit to a level significantly below that seen at drying off.

We observed substantial variation between farms in the prevalence of the different major pathogens as illustrated in Figure 4 (panels a to h). Although Escherichia coli and other coliform organisms were only present on 5 farms at drying off, with a prevalence on affected farms varying between 0.69 and $7.5 \%$, they were identified on 10 and 11 of the 12 farms, respectively, postcalving, with a prevalence varying between 0.53 and $7.69 \%$ and 0.53 and $8.65 \%$, respectively. Gram-negative organisms were identified on 8 farms at drying off and on all 12 farms postcalving. The prevalence of infection with E. coli, coliforms, and all gram-negative organisms was typically lowest at drying off, increased as the dry period progressed, and was higher at calving than at dry off. However, this pattern was not consistent and some herds experienced a decrease in the prevalence of these organisms across the dry period.
Streptococcus uberis was identified on 9 of 12 farms at drying off and on 10 of the 12 farms postcalving, with the prevalence on affected farms varying between 0.53 and $10.48 \%$ and between 0.33 and $3.75 \%$, respectively, demonstrating no real change across the dry period. In contrast, Staph. aureus was identified on only 6 of the 12 farms at drying off (albeit with a prevalence of $14.5 \%$ on one farm), was only identified on 1 farm at each of the 2 sampling points in the dry period, and on 5 farms postcalving. The 2 farms (FR4 and FR5) that had the highest prevalence of Staph. aureus postcalving (5.0 and $5.3 \%$, respectively) were the 2 farms from which $E$. coli was not recovered. In contrast to gram-negative organisms, when all major gram-positive pathogens were considered, they were identified on all farms at all time points, with the prevalence typically, but not exclusively, falling between drying off and 2 wk later before increasing by 6 wk after drying off and decreasing again by the postcalving sample.

The findings with minor pathogens were perhaps more consistent. Coagulase-negative Staphylococcus spp. were identified on all farms at all sampling time points, with the prevalence being highest 6 wk and lowest 2 wk after drying off. Whereas on most farms the prevalence was similar postcalving to that at drying off, 2 farms (BE2 and NL2) experienced a substantial 


\section{a) Dry off}

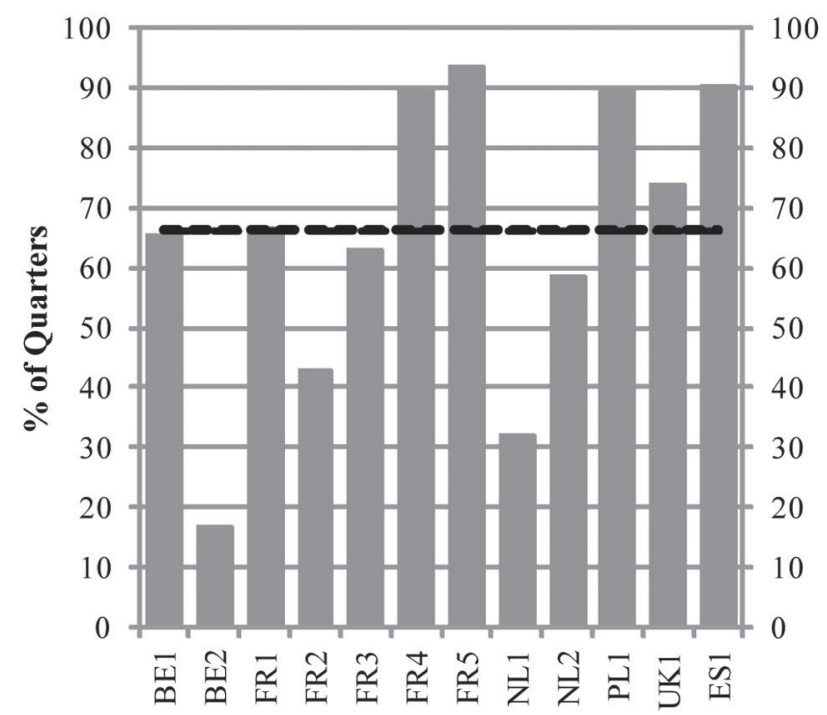

c) 6 weeks after drying off

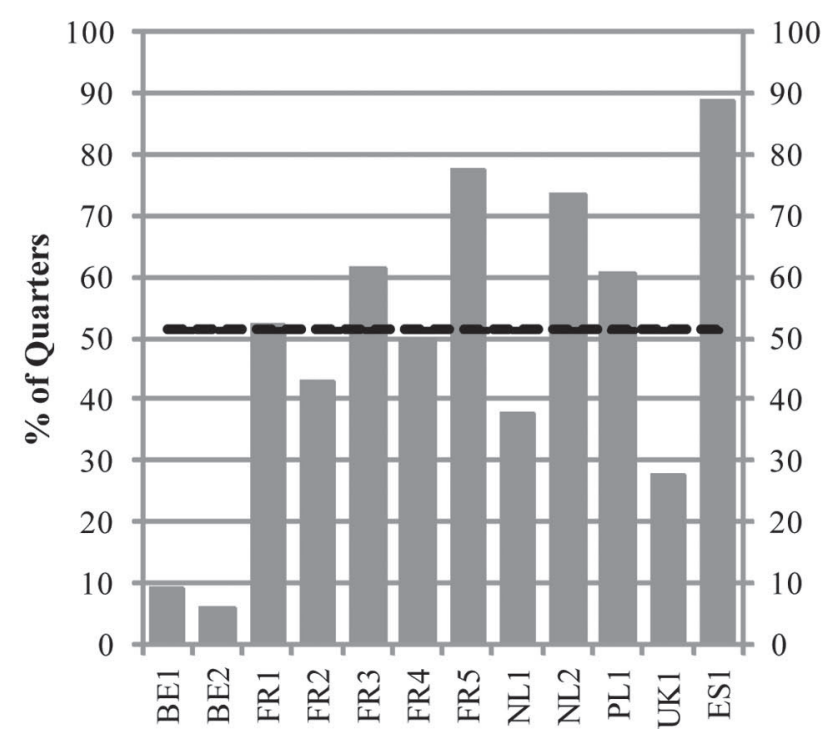

b) 2 weeks after drying off

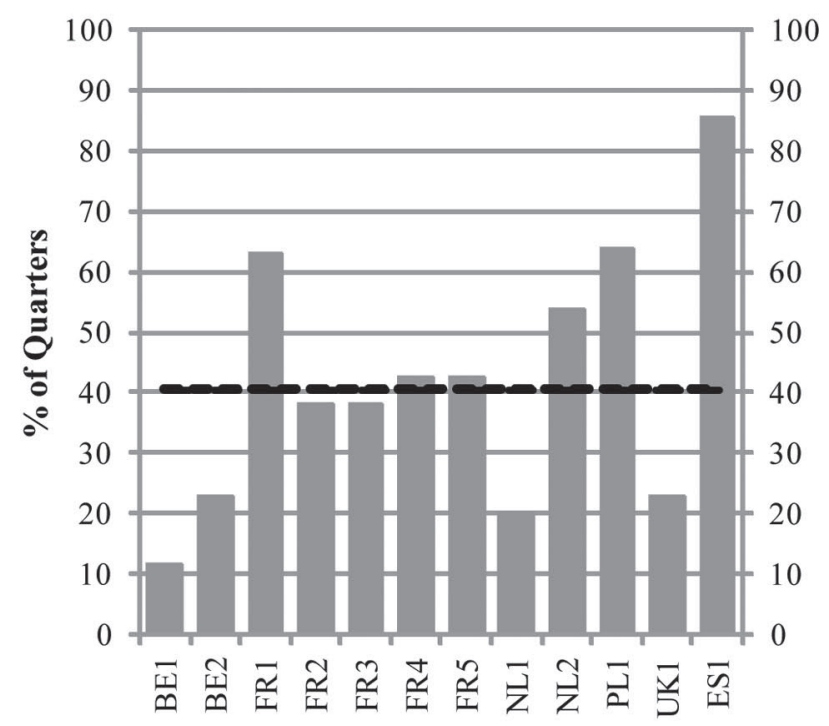

d) Post calving

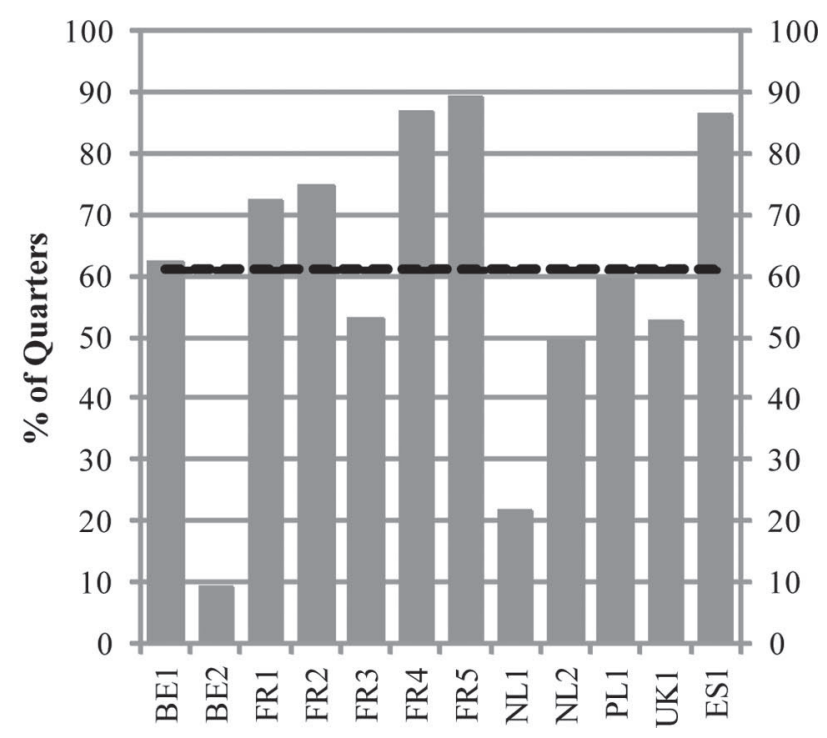

Figure 2. Illustration of the variation in the percentage of teats defined as clean across the 12 study farms at each of the 4 scoring points: (a) dry off; (b) 2 wk after drying off; (c) 6 wk after drying off; and (d) postcalving. Dashed line indicates median percentage of teats defined as clean per farm.

decrease in prevalence across the dry period. The findings with Corynebacterium spp. were less consistent. Corynebacterium spp. were identified on all farms at some stage during the study, but the prevalence varied widely between farms; on 3 farms, the prevalence at drying off was less than $5 \%$, whereas on 5 farms it was in excess of $50 \%$. Most farms experienced a dramatic and significant decrease in the prevalence across the dry period, although 2 farms (FR3 and NL2) experienced a small increase in prevalence.

The apparent origin of pathogens identified postcalving was assessed by determining whether a pathogen identified postcalving had been identified in that quarter at an earlier time point (illustrated in Figure 5). This analysis revealed that the vast majority of organisms identified postcalving were first identified in that 


\section{a) 2 weeks after drying off}

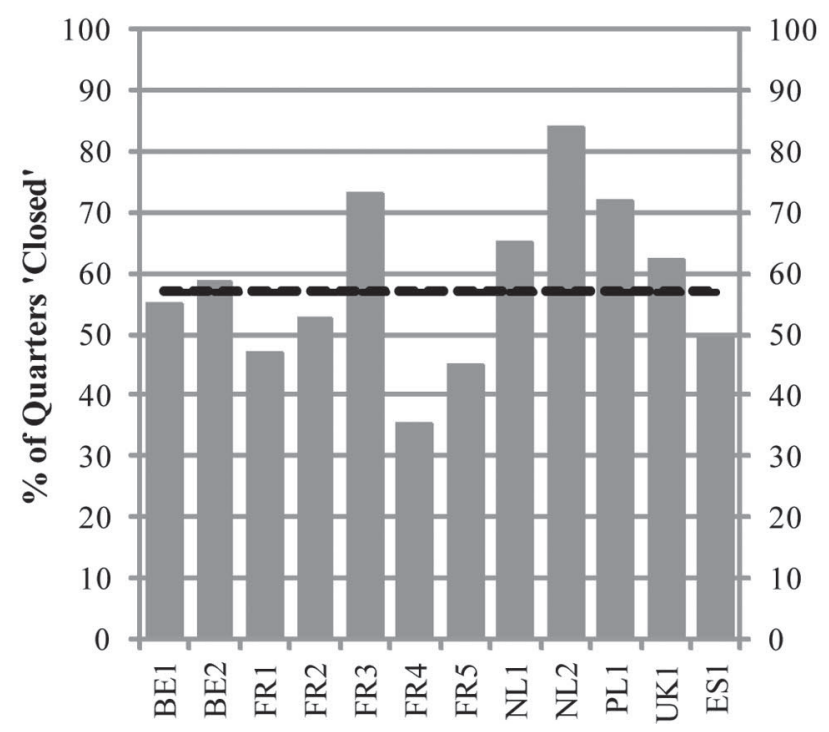

b) 6 weeks after drying off

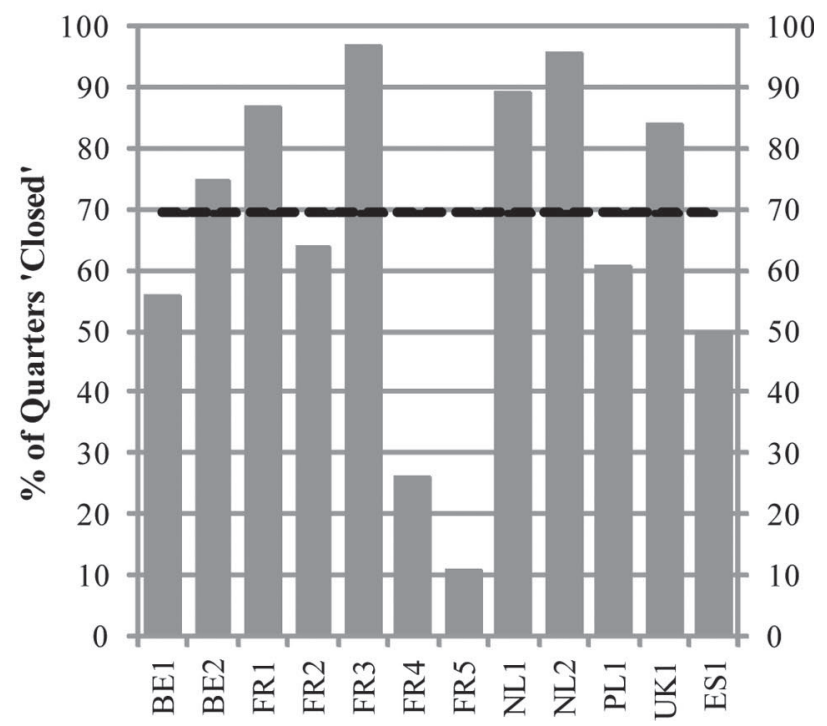

Figure 3. Illustration of the variation in the percentage of teats defined as "closed" across the 12 study farms at each of the dry period sampling points: (a) 2 wk after drying off; (b) 6 wk after drying off. Dashed line indicates median percentage of teats defined as closed per farm.

sample, although there was considerable variation between pathogens. All Staph. aureus identified postcalving were apparently acquired subsequent to the sample 6 wk after drying off, whereas, somewhat surprisingly, almost $30 \%$ of coliforms had been identified in an earlier sample: $5.6 \%$ at drying off and $11.1 \%$ at both 2 and 6 wk after drying off.

An overview of dry period performance was achieved by examining the proportion of quarters identified as being free of any pathogen or free of a major mastitis pathogen and is illustrated in Figures 6 and 7 respectively. With the exception of farm PL1, the dry period was associated with an overall improvement in udder health when measured by the proportion of quarters from which no organism was recovered. However, when minor mastitis pathogens were excluded from the analysis, the picture was less clear, with 5 of the 12 farms experiencing a decrease in the proportion of quarters free of a major mastitis pathogen, and this effect being most marked in farms PL1 and ES1.

A thorough exploration of the data failed to identify any factors associated with the likelihood of being infected with a specific pathogen postcalving. Two models summarizing factors affecting the likelihood of being infected with a gram-positive or gram-negative pathogen postcalving are outlined in Tables 5 and 6 , respectively. The only factor influential in determining if a quarter was likely to be infected with a gramnegative pathogen postcalving was the presence of a gram-negative pathogen in the sample collected $6 \mathrm{wk}$ after drying off. Similarly, the only factor influential in determining if a quarter was likely to be infected with a gram-positive major pathogen postcalving was the presence of a gram-positive pathogen in the sample collected 6 wk after drying off.

\section{DISCUSSION}

Several studies in the modern era have investigated the dynamics of IMI during the nonlactating period (Smith et al., 1985; Todhunter et al., 1991; Bradley and Green, 2000; Dingwell et al., 2004; Green et al., 2005). However, although other studies have been larger in terms of the number of cows studied (Bradley and Green 2000), the current study is probably the most representative of cattle populations as a whole, given that it encompasses data from 12 herds across 6 European countries. The findings of this study are broadly in line with those of earlier studies, although it is evident from this study that there are large variations between farms across all of the major pathogens and pathogen groups.

There are several significant challenges inherent in organizing a large multi-center study, many of which are further compounded when such a study is conducted across several countries. Although this study was commercially funded, there was a limited budget available given that the research was conducted from a perspective of enhancing knowledge rather than specific product development. These constraints inevitably limited some aspects of the study design, although we do not feel they detract from the value of our findings. 
Table 4. Quarter prevalence of mastitis pathogens at each of the sampling time points

\begin{tabular}{|c|c|c|c|c|c|c|c|c|}
\hline Pathogen & \multicolumn{2}{|c|}{$\begin{array}{c}\text { Drying off } \\
(\mathrm{n}=1,816)\end{array}$} & \multicolumn{2}{|c|}{$\begin{array}{l}2 \text { wk after } \\
\text { drying off } \\
(\mathrm{n}=866)\end{array}$} & \multicolumn{2}{|c|}{$\begin{array}{l}6 \text { wk after } \\
\text { drying off } \\
(\mathrm{n}=788)\end{array}$} & \multicolumn{2}{|c|}{$\begin{array}{l}\text { Postcalving } \\
(\mathrm{n}=1,816)\end{array}$} \\
\hline Streptococcus uberis & 46 & $2.53^{\mathrm{a}}$ & 4 & $0.46^{\mathrm{b}}$ & 9 & $1.14^{\mathrm{ab}}$ & 34 & $1.87^{\mathrm{a}}$ \\
\hline Staphylococcus aureus & 36 & $1.98^{\mathrm{a}}$ & 1 & $0.12^{\mathrm{b}}$ & 2 & $0.25^{\mathrm{b}}$ & 16 & $0.88^{\mathrm{b}}$ \\
\hline Micrococcus spp. & 25 & 1.38 & 14 & 1.62 & 8 & 1.02 & 25 & 1.38 \\
\hline Yeast and fungal species & 19 & 1.05 & 5 & 0.58 & 5 & 0.63 & 18 & 0.99 \\
\hline Enterococcus spp. & 15 & 0.83 & 9 & 1.04 & 15 & 1.90 & 28 & 1.54 \\
\hline Other Streptococcus spp. & 14 & 0.77 & 2 & 0.23 & 5 & 0.63 & 13 & 0.72 \\
\hline Acinetobacter spp. & 12 & 0.66 & 1 & 0.12 & 7 & 0.89 & 6 & 0.33 \\
\hline Bacillus spp. & 11 & 0.61 & 10 & 1.15 & 12 & 1.52 & 5 & 0.28 \\
\hline Pseudomonas spp. & 7 & 0.39 & 2 & 0.23 & 5 & 0.63 & 17 & 0.94 \\
\hline Streptococcus dysgalactiae & 6 & 0.33 & 0 & 0.00 & 3 & 0.38 & 14 & 0.77 \\
\hline Pantoea spp. & 0 & 0.00 & 2 & 0.23 & 4 & 0.51 & 2 & 0.11 \\
\hline Trueperella spp. & 0 & 0.00 & 1 & 0.12 & 1 & 0.13 & 2 & 0.11 \\
\hline Raoultella spp. & 0 & 0.00 & 2 & 0.23 & 0 & 0.00 & 0 & 0.00 \\
\hline Buttiauxella spp. & 0 & 0.00 & 0 & 0.00 & 1 & 0.13 & 0 & 0.00 \\
\hline Kluyvera spp. & 0 & 0.00 & 0 & 0.00 & 0 & 0.00 & 1 & 0.06 \\
\hline Morganella spp. & 0 & 0.00 & 0 & 0.00 & 2 & 0.25 & 0 & 0.00 \\
\hline Providencia spp. & 0 & 0.00 & 0 & 0.00 & 1 & 0.13 & 0 & 0.00 \\
\hline Salmonella spp. & 0 & 0.00 & 0 & 0.00 & 1 & 0.13 & 0 & 0.00 \\
\hline Prototheca spp. & 0 & 0.00 & 0 & 0.00 & 0 & 0.00 & 2 & 0.11 \\
\hline Coliforms & 23 & $1.27^{\mathrm{a}}$ & 13 & $1.50^{\mathrm{ab}}$ & 29 & $3.68^{\mathrm{c}}$ & 49 & $2.70^{\mathrm{bc}}$ \\
\hline All gram-negative bacteria ${ }^{1}$ & 51 & $2.81^{\mathrm{a}}$ & 25 & $2.89^{\mathrm{ab}}$ & 47 & $5.96^{\mathrm{c}}$ & 87 & $4.79^{\mathrm{bc}}$ \\
\hline All gram-positive bacteria ${ }^{1}$ & 172 & $9.47^{\mathrm{a}}$ & 53 & $6.12^{\mathrm{b}}$ & 69 & $8.76^{\mathrm{b}}$ & 153 & $8.43^{\mathrm{b}}$ \\
\hline \multicolumn{9}{|l|}{ Minor pathogens } \\
\hline CNS & 354 & $19.49^{\mathrm{a}}$ & 115 & $13.28^{\mathrm{b}}$ & 224 & $28.43^{\mathrm{c}}$ & 299 & $16.46^{\mathrm{d}}$ \\
\hline
\end{tabular}

${ }^{\mathrm{a}-\mathrm{d}}$ Values within rows with different superscripts are significantly different $(P<0.05)$.

${ }^{1}$ Totals may differ from organisms listed above due to unlisted unspeciated organisms. Overall column totals may not equal sum of the individual pathogens as a result of mixed infections.

A prestudy meeting was held to refine the study design and agree on standard operating procedures; this will have helped reduce, but could not have eliminated, operator variation across the study, which may have accounted for some of the variability observed across farms and countries.

Another challenge in exploring data in a large epidemiological study such as this is how to group and categorize sampling time points. For the purposes of the analysis for this paper, we chose to define fixed periods from dry off as opposed to precalving. Given the dry period lengths in this study, this meant that the samples broadly split the dry period into early, mid, and late phases, which fits with the perceived period of risk (Bradley and Green, 2004). To investigate the validity of this approach, we did investigate the prevalence of infection relative to calving for some pathogens. In the case of coliforms, the absolute prevalence did increase as the timing of the " 6 -wk" sample approached calving, but this effect was not significant.

Another challenge in a study such as this is defining the exact timing of IMI, particularly around the time of calving. Sampling too close to calving may mean that the ability to detect infections is compromised by the continued presence of inhibitory substance from any dry cow therapy; sampling later will increase the chance that any pathogens identified may have entered the gland after calving and not during the nonlactating period. Newton et al. (2008) identified no significant difference in infection status when examining samples collected at $4 \mathrm{~d}$ or 8 to $11 \mathrm{~d}$ postcalving. Godden et al. (2003) identified fewer infections when sampling at 6 to 8 DIM than at 1 to 3 DIM, and they hypothesized that this was due to self-cure. These and other studies suggest that although the exact timing of sampling may have some effect, it is unlikely that our protocol 
resulted in an overestimation of the importance of the dry period, although the possibility remains that some of the pathogens we identified were acquired in the immediate postpartum period.

A diverse range of organisms was isolated in this study, with over 50 different genera identified. This level of identification was enabled by the use of MALDI-TOF MS for bacterial identification. Although this relatively new technique has not been extensively used in mastitis diagnostics, some small-scale studies have demonstrated its utility in this field (Barreiro et al., 2010). In addition, extensive in-house validation, funded by the UK Technology Strategy Board, was undertaken by the laboratory used in this study (Quality Milk Management Services Ltd.) and the instrument has the In Vitro Diagnostics (IVD)-CE mark with a Declaration of Conformity in accordance with the European Commission (1998). Although novel, high-throughput, proteomic techniques such as that used in this study have yet to be widely adopted and fully validated in the field of mastitis research, they are now widely used in the field of human medicine and are acknowledged as "more accurate than conventional identification methods for the identification of most bacterial and fungal clinical isolates" (Dingle and Butler-Wu, 2013) and may offer the opportunity to extend our knowledge and understanding of bovine mastitis etiology.

There is much debate on how best to define an IMI. We took the view in this study that we wanted to maximize sensitivity, and although single or duplicate samples and their interpretation can have a small influence on identification of an IMI, it is accepted that a single isolation offers the best sensitivity without a significant deterioration in specificity (Griffin et al., 1987; Dohoo et al., 2011). In this study, as well as using an increased volume of inoculum on MacConkey agar to enhance the detection of the Enterobacteriaceae, we chose to transparently report and classify isolation of an organism as an IMI, rather than applying a higher threshold for definition of an IMI. This approach will have had its merits and demerits; it will have increased the sensitivity of our approach but will also have affected the specificity of our definition. Thus, we may have overestimated the prevalence of infection during the dry period compared with some other methods but will have also ensured that we have not underestimated the potential importance of the dry period.

Body condition score data from across the herds suggested that nutritional management varied considerably between the herds; some of the variation in BCS could be explained by breed differences, but as the predominant breed was Holstein Friesian, this was more likely to represent nutritional management. In some herds, a significant number of cows were over- or underconditioned, with over half of all cows experiencing a change in BCS across the dry period. Although this is not a problem per se, poor BCS management has been associated with no change or an increased risk of disease (Zadoks et al., 2001; Breen et al., 2009a), whereas proactive management has been associated with a decreased risk (Green et al., 2007).

In this study, we observed large variation in teat cleanliness between the different farms. Teats were typically dirtier in the dry period than at dry off or postcalving, although this was not reflected in all herds. Interestingly, and somewhat counter intuitively, despite poor udder hygiene being identified as a risk factor for IMI in some studies (Schreiner and Ruegg, 2003; Arruda et al., 2013), dirtier teats were not associated with an increase in the risk of infection during the dry period or postcalving.

Teat closure was assessed in a similar way to that described by Williamson et al. (1995); however, contrary to earlier findings (Williamson et al., 1995; Dingwell et al., 2004), slower teat closure or failure of teat closure was not associated with an increase in the risk of IMI in this study, either during the dry period or postcalving. This finding is surprising, not least because of the high proportion of dirty teats on some farms. The proportion of teats defined as closed generally increased across the dry period, though notably the proportion decreased markedly in herds FR4 and FR5 as the dry period progressed and it was these herds that experienced the highest proportion of quarters infected with Staph. aureus postcalving, suggesting that failure of teat closure may predispose to infection with this pathogen. There is a need for further research to increase our understanding of the mechanisms and protection offered by formation of the keratin plug in the dry period.

In addition to finding no increase in the rate of new IMI associated with teat cleanliness or failure of teat closure, we also found no interaction between teat cleanliness and closure with respect to the risk of new IMI. It would seem biologically plausible that open dirty teats should be at significantly more risk than closed clean teats, yet we found no such effect. This could have been as a result of insufficient power in the study, though it seems unlikely that a biologically important effect would have been missed, given the number of cows recruited. Another possibility is that the number and timing of assessments was insufficiently sensitive to detect any effect. However, it may be that other factors of which we are not currently aware may be more influential than one might expect.

With respect to the dynamics of infection during the dry period, it is clear that a large amount of betweenfarm variation exists in both the actual pathogens causing IMI and the prevalence of such infections. It is 


\section{a) Escherichia coli}

Dry off

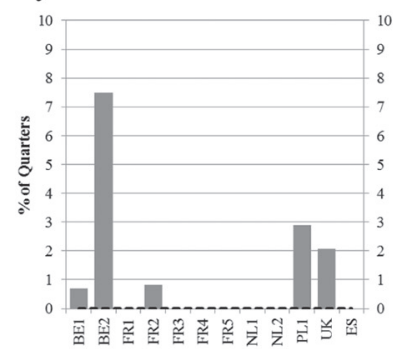

b) Coliforms

Dry off

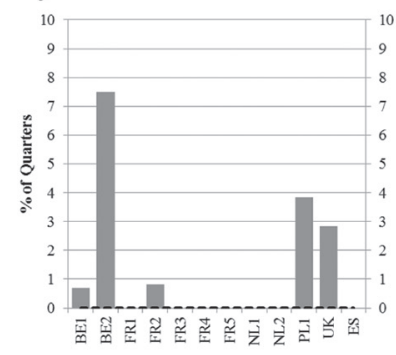

c) All Gram-negatives

Dry off

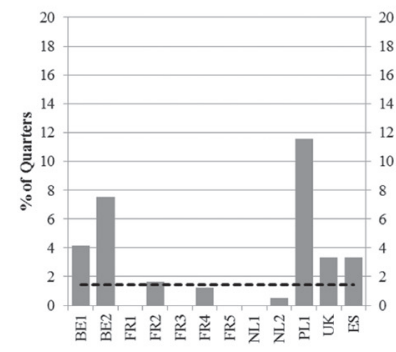

d) Streptococcus uberis

Dry off

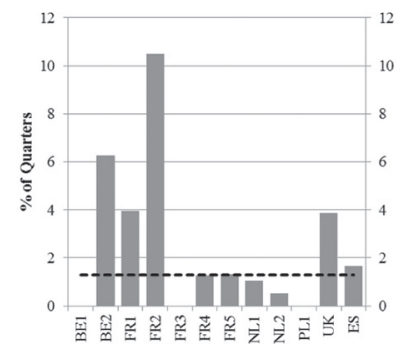

2 weeks after dry off

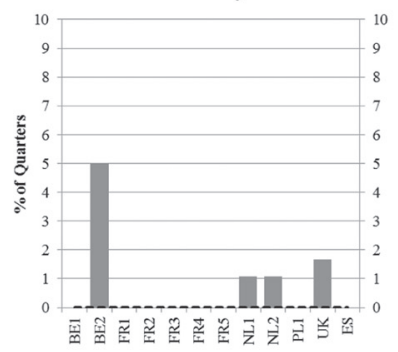

2 weeks after dry off

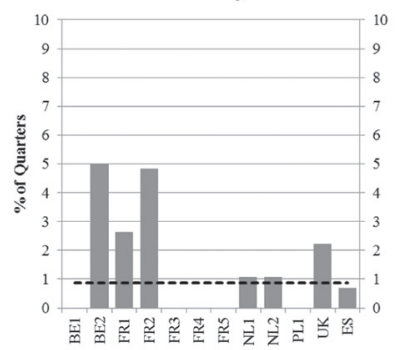

2 weeks after dry off

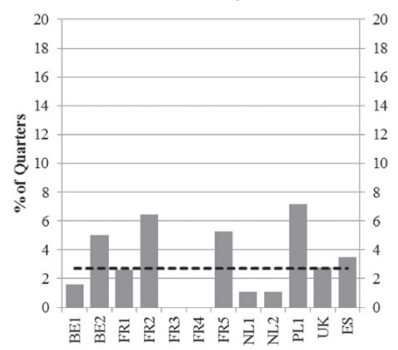

2 weeks after dry off

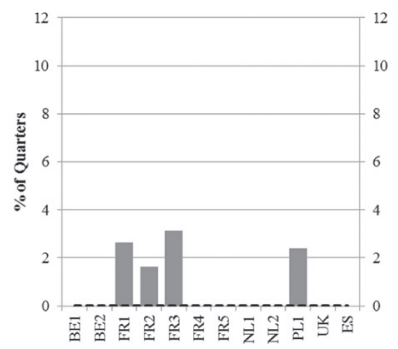

6 weeks after dry off

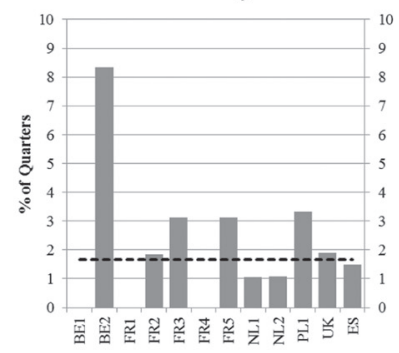

6 weeks after dry off

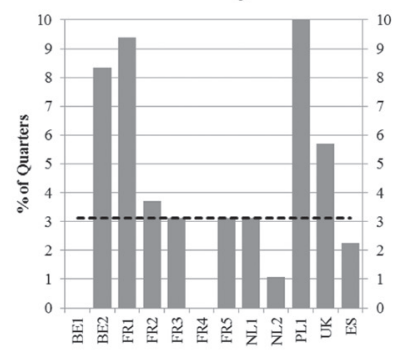

6 weeks after dry off

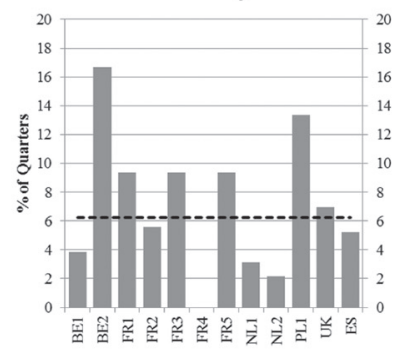

6 weeks after dry off

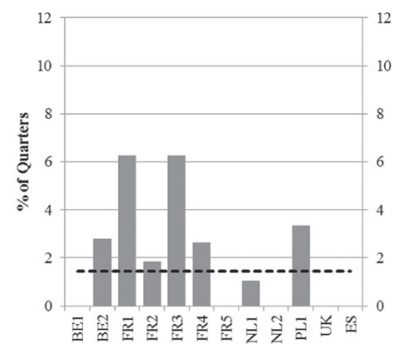

Post calving

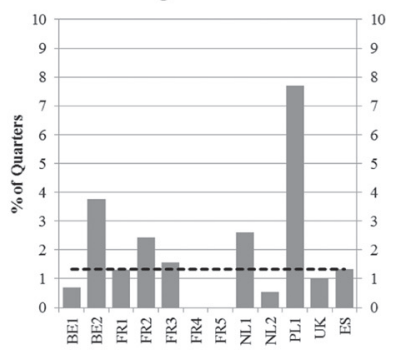

Post calving

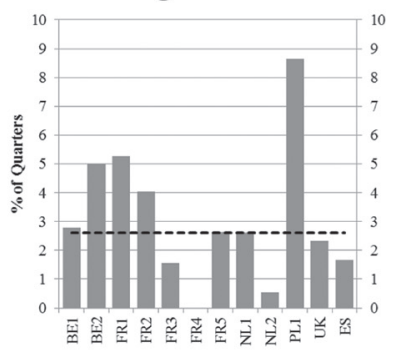

Post calving

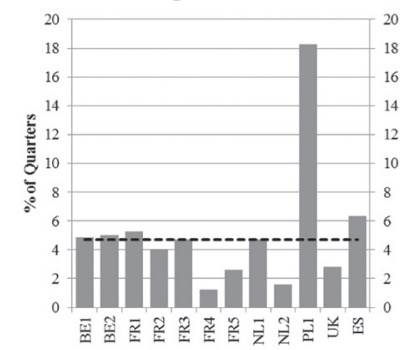

Post calving

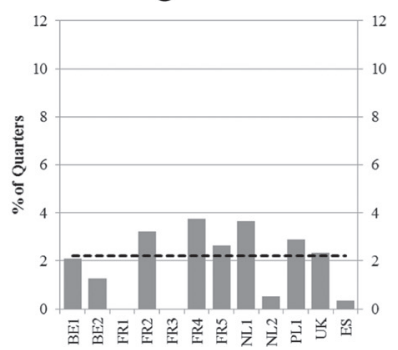

Figure 4. Illustration of the variation in culture results for key pathogens and pathogen groups, at each sampling time point, across the 12 study farms. Dashed line indicates median percentage of teats infected with the pathogen or pathogen group per farm.

interesting to note that gram-positive and gram-negative infections do not appear to be mutually exclusive and that some herds can apparently be free of either coliforms or environmental streptococci postcalving but not both. The pathogens that appear to behave most consistently across the dry period are the minor pathogens; in particular, the prevalence of the CNS was remarkably consistent across the different farms, and it would be of interest to see if this consistency were preserved if we considered different species individually.

One aim of this study was to better understand the timing of acquisition and implication of a quarter being 
e) Staphylococcus aureus Dry off

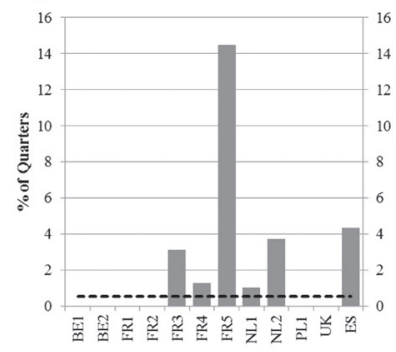

f) All Gram-positives

Dry off

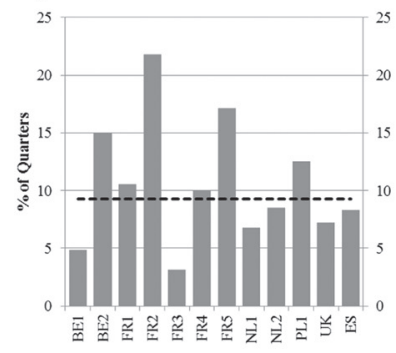

2 weeks after dry off

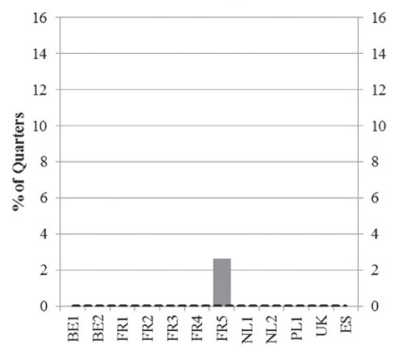

2 weeks after dry off

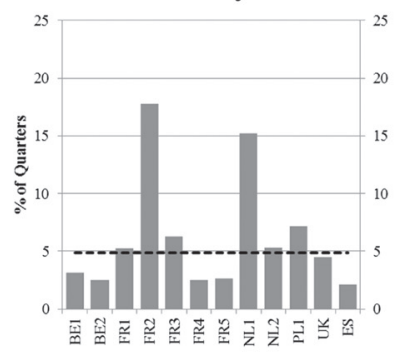

6 weeks after dry off

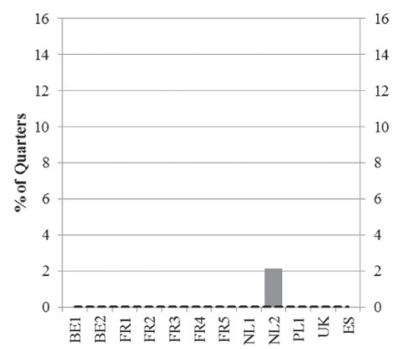

6 weeks after dry off

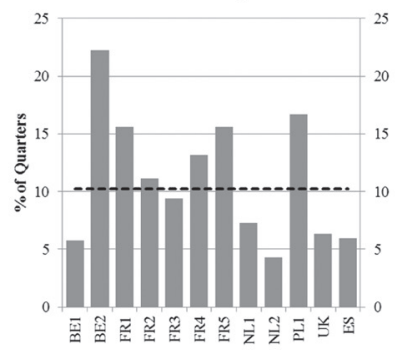

Post calving

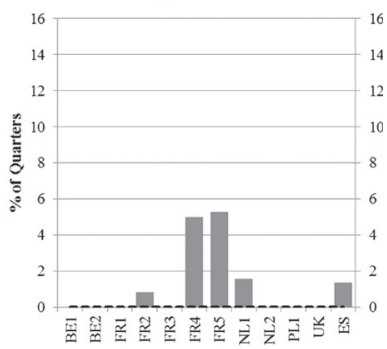

Post calving

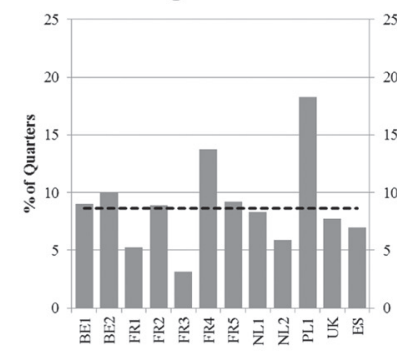

\section{g) Coagulase-negative Staphylococcus spp.}

Dry off

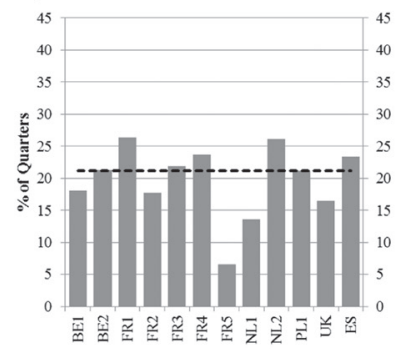

h) Corynebacterium spp.

Dry off

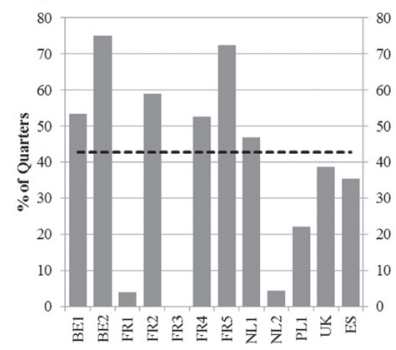

2 weeks after dry off

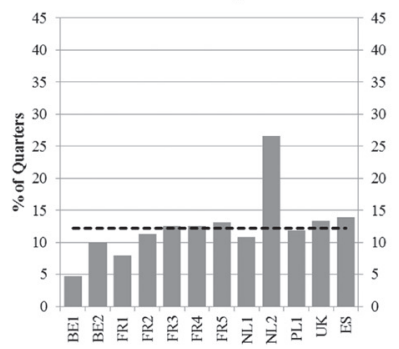

2 weeks after dry off

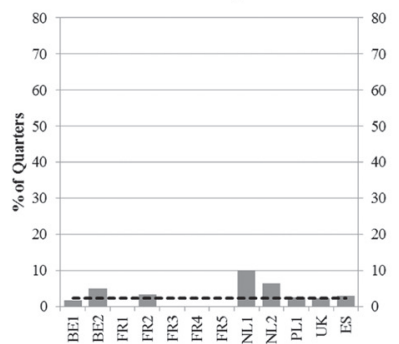

6 weeks after dry off

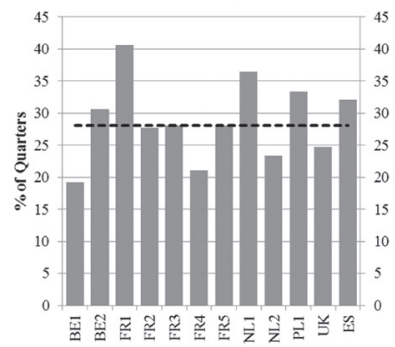

6 weeks after dry off

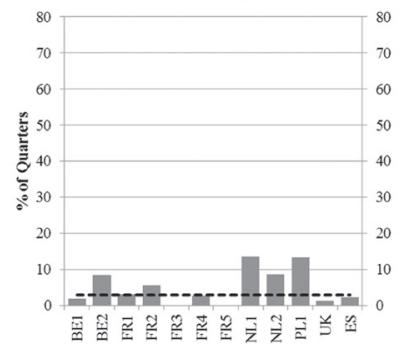

Post calving

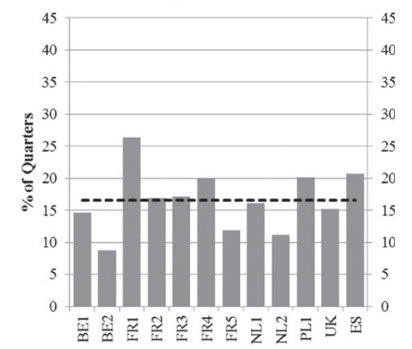

Post calving

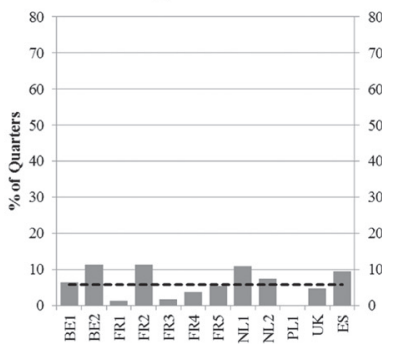

Figure 4 (Continued). Illustration of the variation in culture results for key pathogens and pathogen groups, at each sampling time point, across the 12 study farms. Dashed line indicates median percentage of teats infected with the pathogen or pathogen group per farm.

infected during the dry period. Overall, more grampositive major pathogens were identified than gramnegative organisms, although E. coli was the second most prevalent organism present postcalving. Gramnegative organisms predominated on some farms and gram-positive organisms on others. Quarters apparently acquired several different pathogens throughout the dry period, though this study appears to question some previously strongly held beliefs. Staphylococcus aureus appeared to be well controlled on all farms with 
a) First detected at drying off

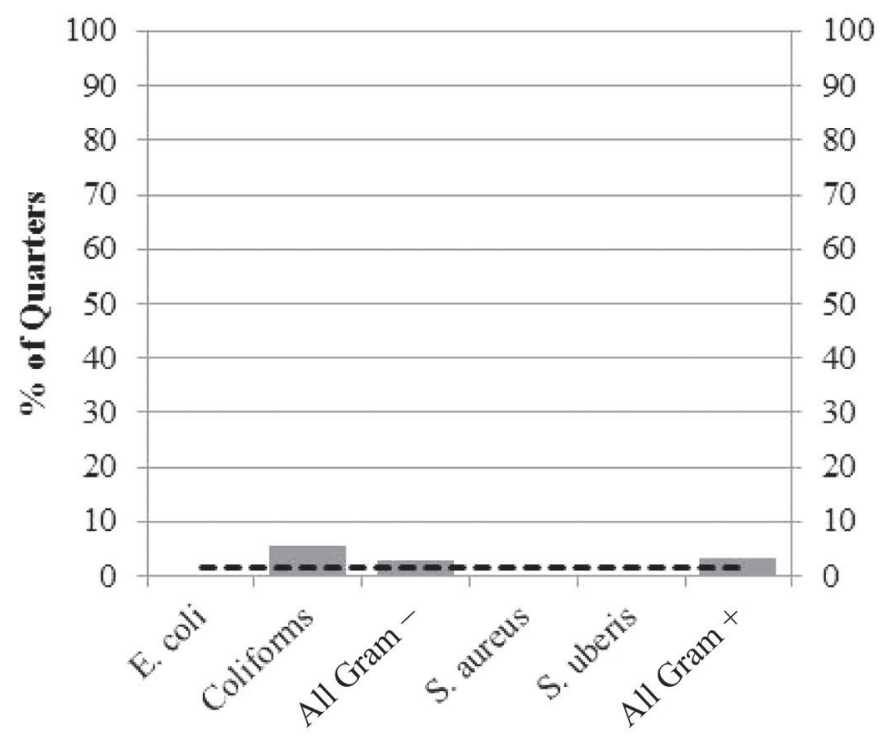

c) First detected 6 weeks after drying off

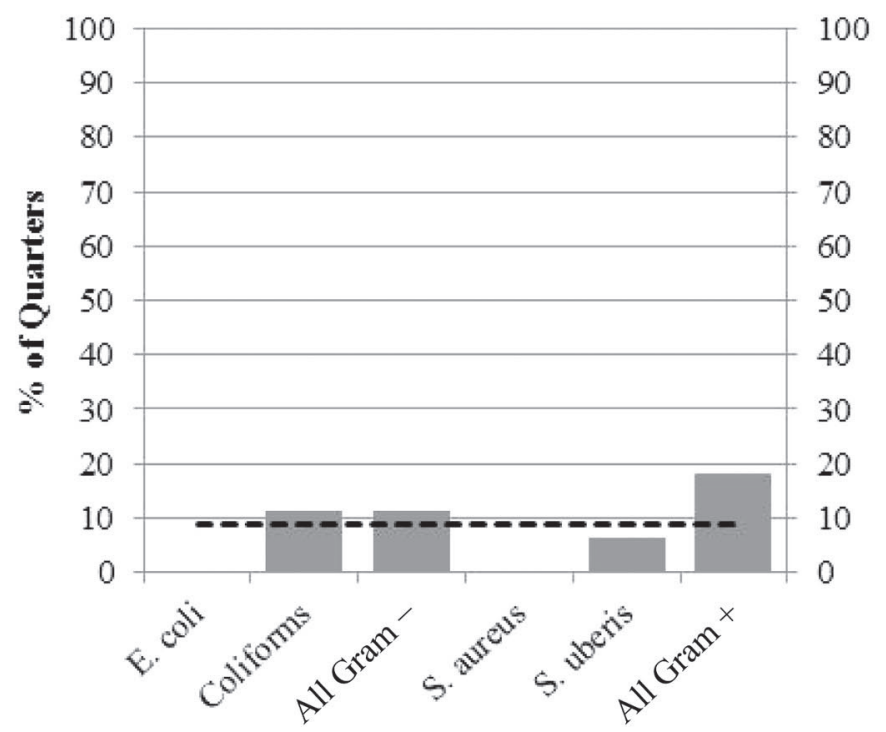

b) First detected 2 weeks after drying off

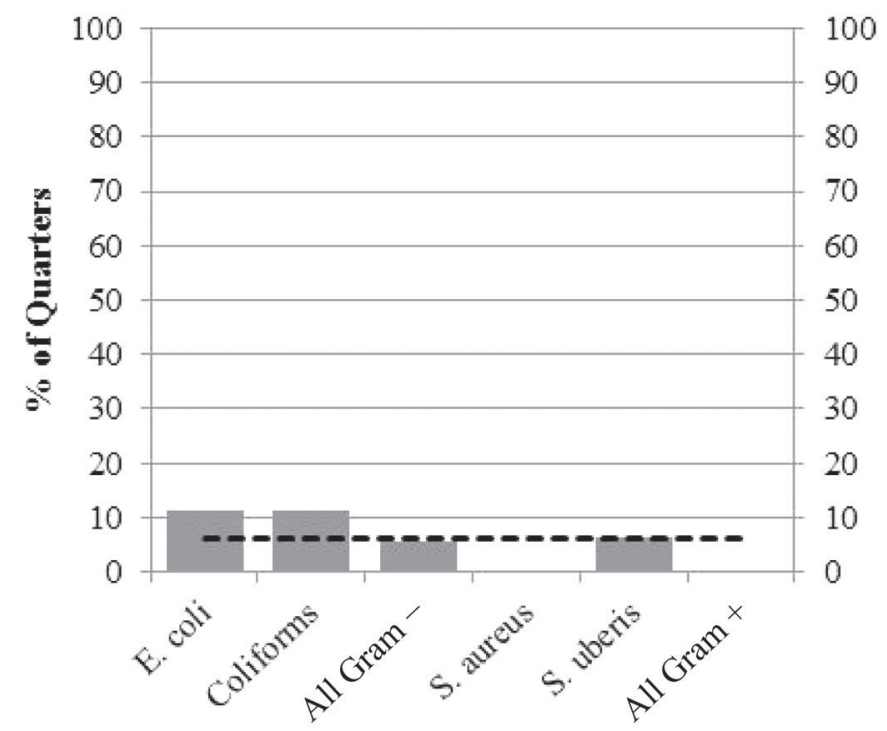

d) First detected post calving

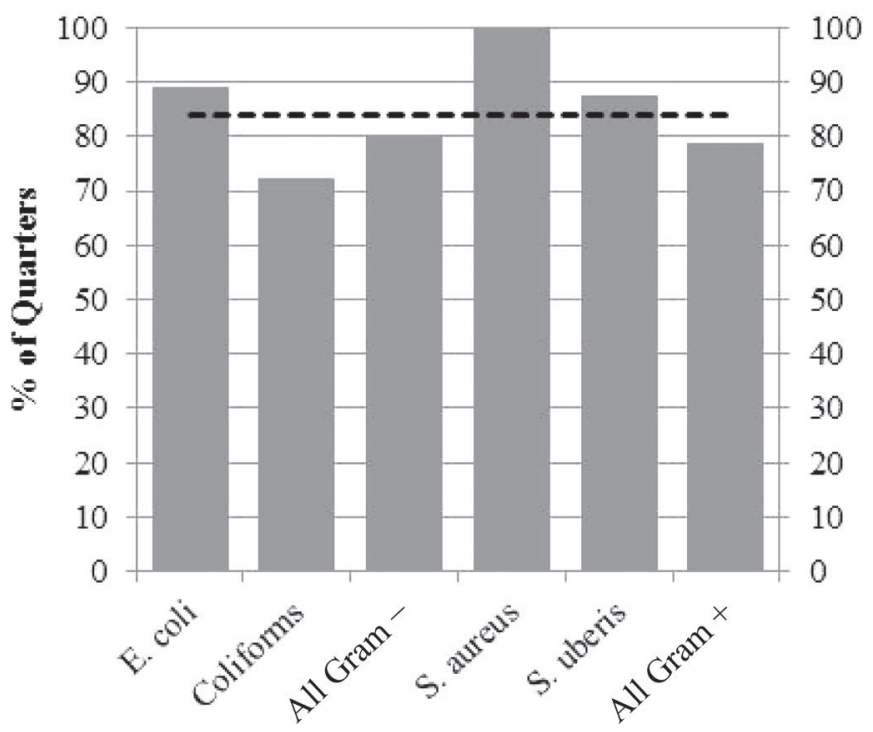

Figure 5. Illustration of the apparent origin of key pathogens and pathogen groups present postcalving: (a) first detected at drying off; (b) first detected 2 wk after drying off; (c) first detected 6 wk after drying off; and (d) first detected postcalving. Dashed line indicates median percentage of all pathogens present postcalving that were first detected at the given time point.

apparent cure rates of $100 \%$ - all quarters found to be infected postcalving were first identified at this stage, implying that infection was only acquired late in the dry period or immediately postpartum. In contrast, the picture was less clear with the gram-negative organisms and environmental gram-positive organisms, where 20 to $30 \%$ of those quarters found to be infected postcalving had previously been found to be positive for that pathogen. Coliforms other than E. coli appear to be more likely to persist across the dry period, suggesting that it may be better to consider these separately rather than as a homogeneous group. This study has demonstrated that the etiology of IMI in the dry period is diverse and inconsistent between farms, highlighting the importance of the practitioner understanding infection dynamics on individual farms and the dangers of making general assumptions about pathogen behavior during the dry period. 
a) Drying off

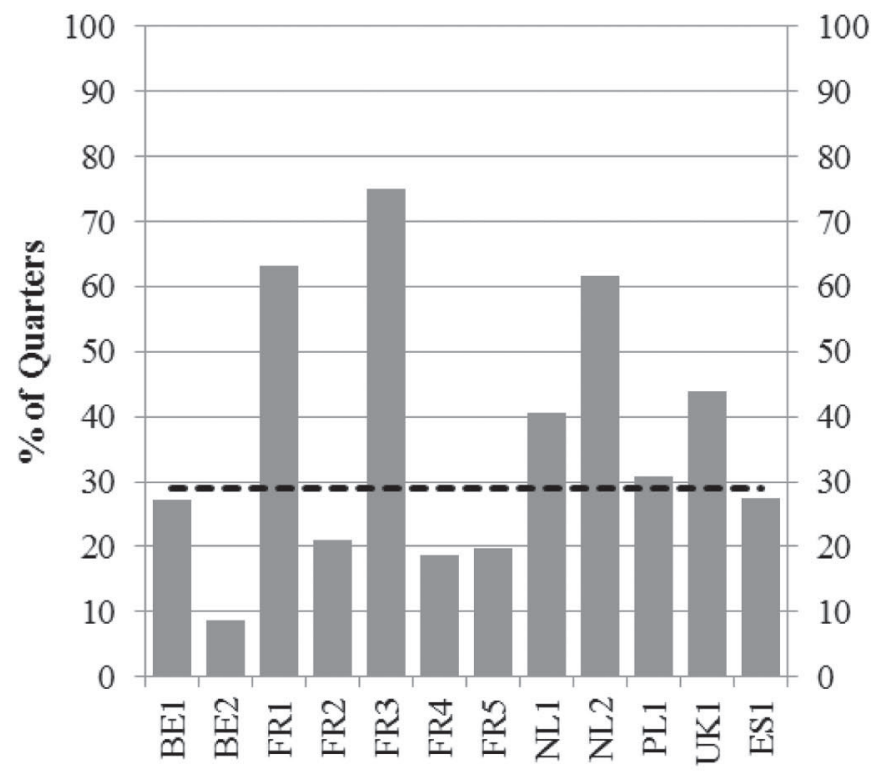

c) 6 weeks after drying off

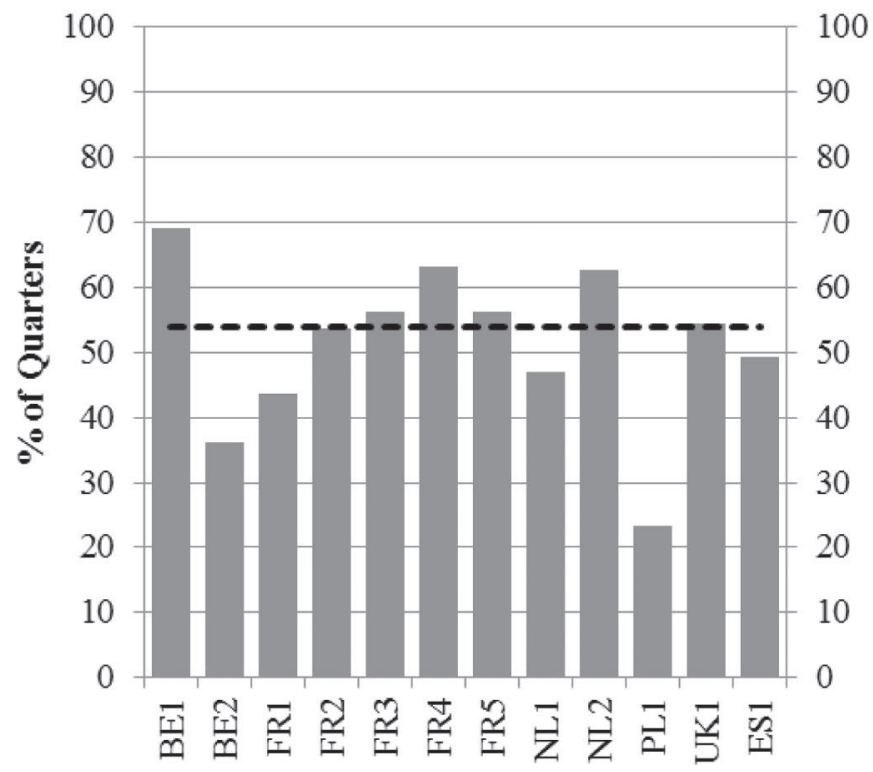

b) 2 weeks after drying off

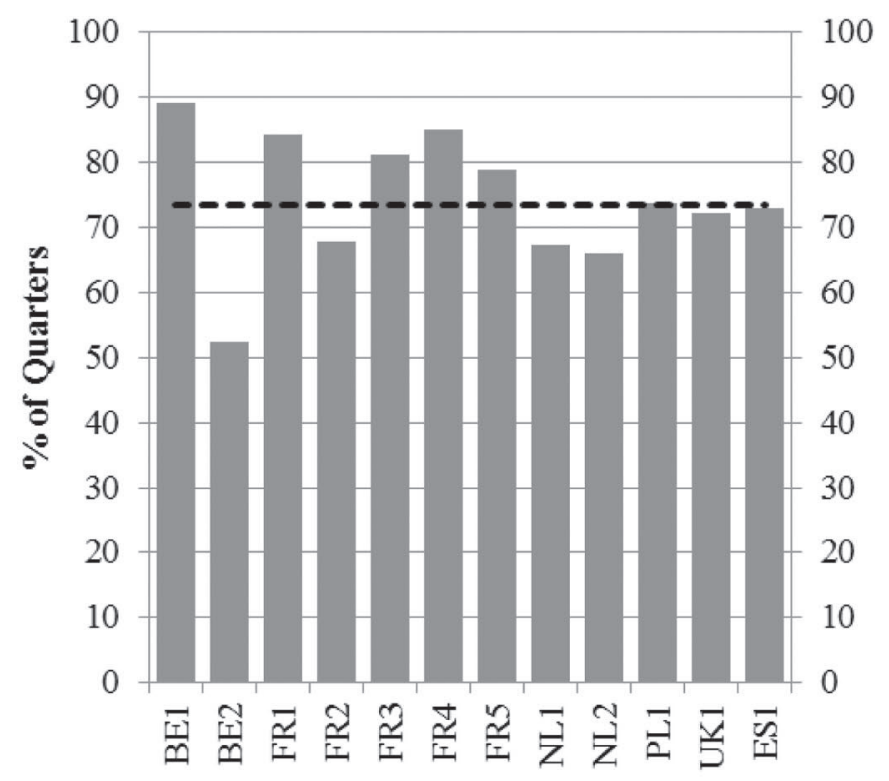

d) Post calving

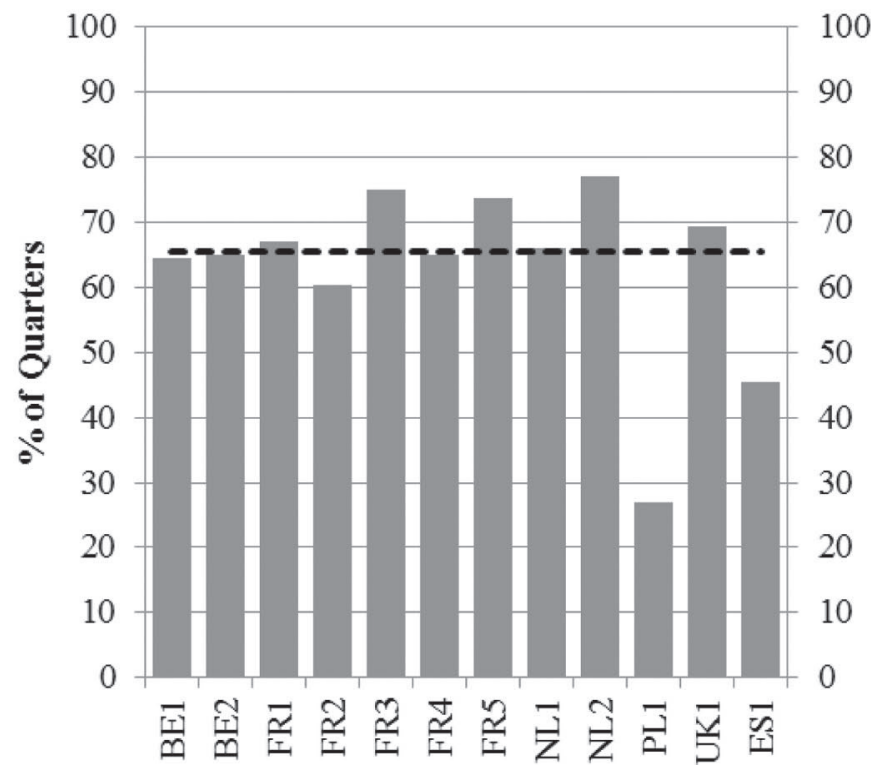

Figure 6. Illustration of the variation in the proportion of quarters from which "no growth" was obtained, at each sampling time point, across the 12 study farms: (a) dry off; (b) 2 wk after drying off; (c) 6 wk after drying off; and (d) postcalving. Dashed line indicates median percentage of quarters defined as "no growth" per farm.

The presence of a gram-positive or gram-negative pathogen in the sample collected 6 wk after drying off was associated with an increase in the risk of being infected with a gram-positive or gram-negative pathogen, respectively. However, this was not on a species-specific basis and did not transfer between the 2 groups, suggesting that factors affecting susceptibility to gram-positive or gram-negative infection may not be the same.
As well as investigating pathogen-specific effects, we also assessed the likelihood of a quarter being free of any mastitis pathogen or a major mastitis pathogen. It was clear from this analysis that the likelihood of being pathogen free increased across the dry period, although the zenith was reached 2 wk after drying off. Interestingly, in herds FR1 and FR3, the dry period was not associated with a change in the proportion of quarters 
a) Drying off

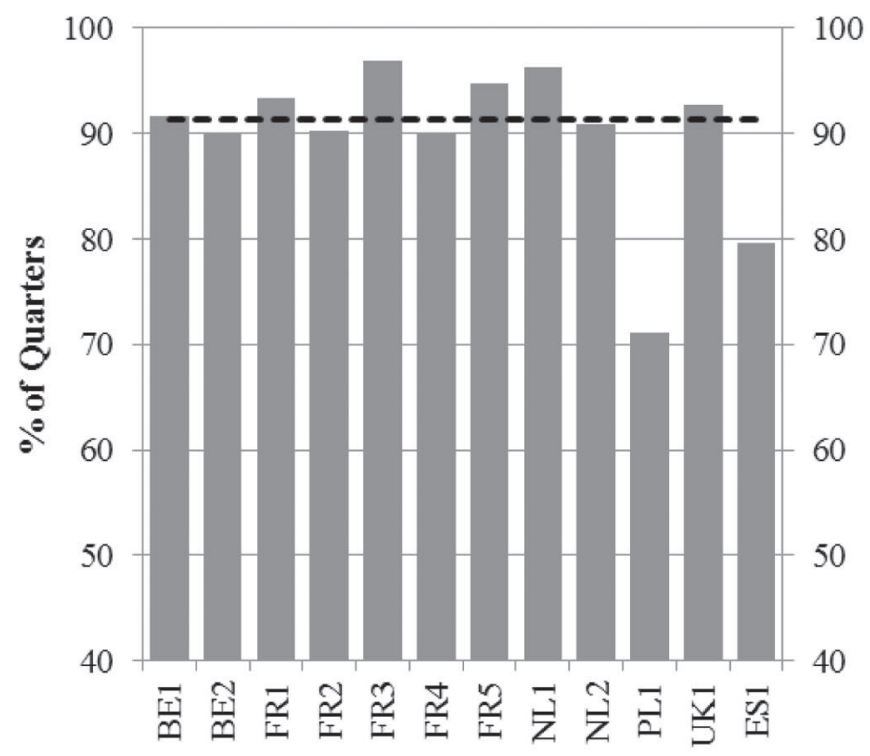

c) 6 weeks after drying off

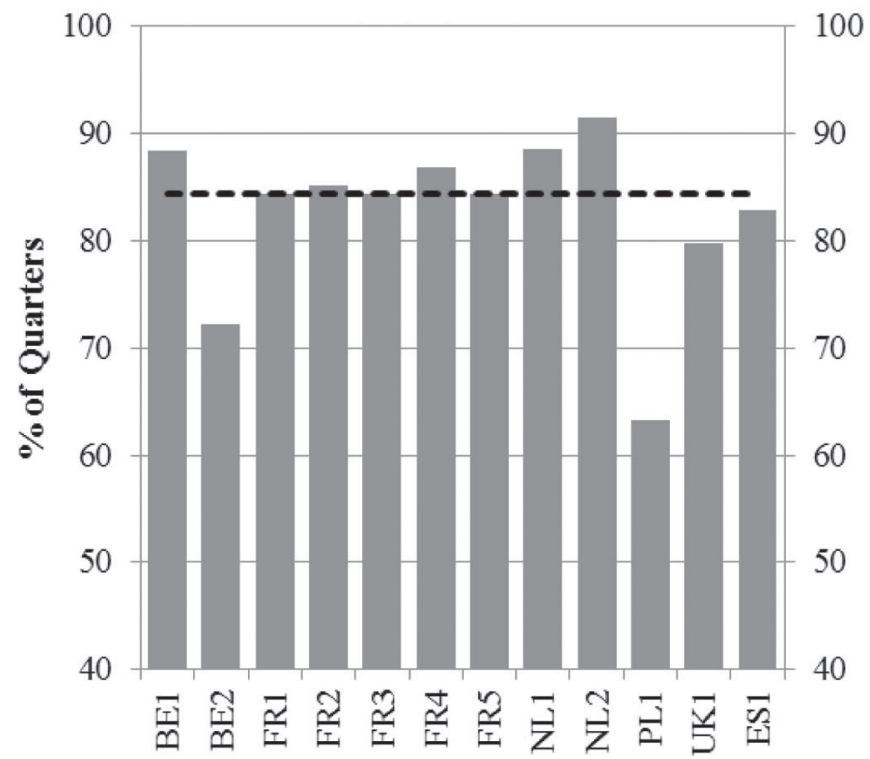

b) 2 weeks after drying off

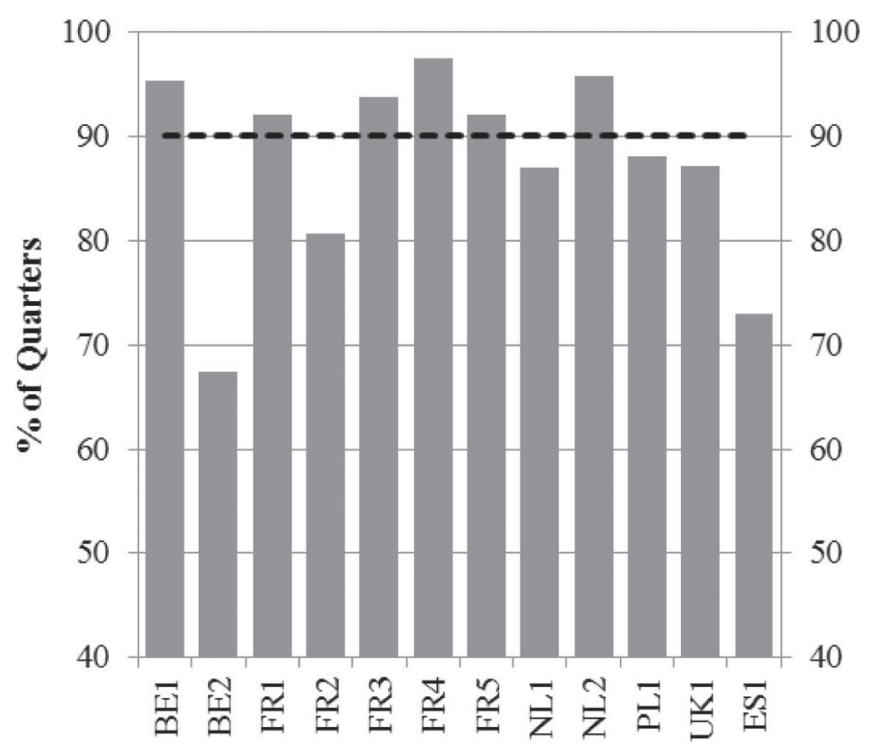

c) Post calving

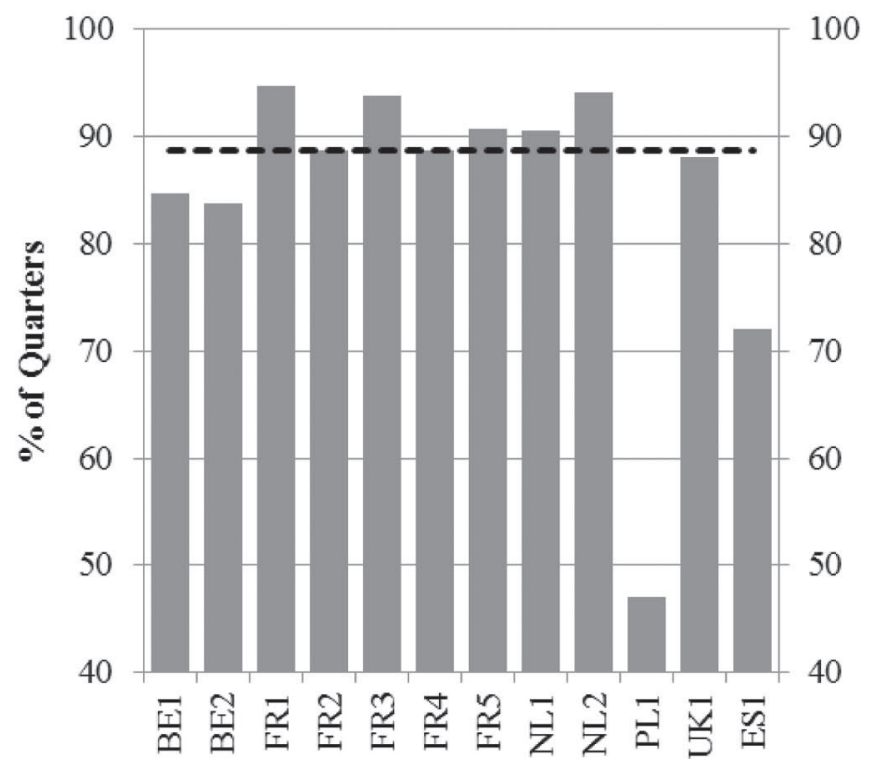

Figure 7. Illustration of the variation in the proportion of quarters free of a major mastitis pathogen, at each sampling time point, across the 12 study farms: (a) dry off; (b) 2 wk after drying off; (c) 6 wk after drying off; and (d) postcalving. Dashed line indicates median percentage of quarters defined as free of a major mastitis pathogen per farm.

defined as free of a mastitis pathogen, although these herds (along with NL2) were notable for a very low prevalence of Corynebacterium spp. at drying off. In contrast, the likelihood of being free of a major mastitis pathogen remained remarkably stable in most herds, with only herd PL1 experiencing more than a relative $10 \%$ decrease in the proportion of quarters defined free of a major pathogen. Arguably, these findings are an excellent advocate for the success of the use of antibiotic dry cow therapy, and undoubtedly this study again confirms the efficacy of this approach in the removal of existing infections. Nevertheless, that view needs to be tempered by the fact that the overwhelming proportion of infections present postcalving were new infections, 
Table 5. A summary of the model explaining the likelihood of being infected with a gram-negative pathogen postcalving

\begin{tabular}{|c|c|c|c|c|c|}
\hline Term & Coefficient & $\mathrm{SE}$ & $\begin{array}{c}\text { Hazard } \\
\text { ratio }\end{array}$ & \multicolumn{2}{|c|}{$95 \%$ CI } \\
\hline $\begin{array}{l}\text { Presence of a gram-negative pathogen } 6 \text { wk after dry off } \\
\text { Reference = Belgium }\end{array}$ & 1.19 & 0.52 & 3.30 & 1.18 & 9.18 \\
\hline France & -0.62 & 0.67 & 0.54 & 0.14 & 2.08 \\
\hline The Netherlands & -0.69 & 0.70 & 0.50 & 0.12 & 2.03 \\
\hline Poland & 1.50 & 0.81 & 4.46 & 0.88 & 22.62 \\
\hline Cow-level variance & 1.44 & 0.82 & & 0.81 & 21.82 \\
\hline
\end{tabular}

acquired during the dry period, and the majority of those occurred in quarters that were uninfected at drying off.

No cows included in this study received an internal teat sealant, which probably still reflects the predominant management approach across the European Union (with perhaps the exception of the UK). An ever-increasing number of studies continue to demonstrate the efficacy of internal teat sealants with respect to prevention of new IMI in the dry period (Huxley et al., 2002; Rabiee and Lean, 2013), whereas others have identified the use of narrow-spectrum antibiotic dry cow therapy as a risk factor for acquisition of new IMI and subsequent clinical mastitis caused by gramnegative organism. It would be interesting and relevant to investigate any changes in infection dynamics that may occur following a more strategic approach to antibiotic dry cow therapy (Schukken et al., 1989; Bradley and Green, 2001; Bradley et al., 2011). While there was a broad range of different antibiotic dry cow therapies used on farms in this study, it was not possible to attribute any difference in infection dynamics to the products used, even when they were more loosely classified as narrow or broad spectrum. This was not surprising given that there were no fixed criteria defining product selection and other herd factors are likely to have been influential.
Perhaps the most intriguing finding of this study was the failure to identify, with the exception of the presence of infection in the sample collected 6 wk after drying off, any significant factors influencing the likelihood of infection with a specific pathogen or pathogen group either postcalving or during the dry period. The size of the study and the number of cows recruited on some farms meant that we needed to group farms for the purposes of multivariable analysis; we did this at the country level, given that in those countries where more than one farm was recruited, they were in a relatively tight geographical area. Although multivariable analysis demonstrated some variation between countries in overall gram-positive pathogen rates, it was not possible to establish an association with any of the measured cow or quarter variables. In contrast to earlier studies, we failed to identify any increase in risk associated with failure of teat closure (Williamson et al., 1995; Dingwell et al., 2004), teat cleanliness, yield at drying off (Huxley et al., 2002; Dingwell et al., 2004), SCC in the previous lactation (Pinedo et al., 2012), absolute BCS or change in BCS (Breen et al., 2009a) or antibiotic dry cow therapy type (Bradley et al., 2001, 2011). With respect to dry cow therapy, this is perhaps not surprising given that the cited studies were typically randomized control trials. However, the other findings are more surprising and may reflect the importance of

Table 6. A summary of the model explaining the likelihood of being infected with a gram-positive pathogen postcalving

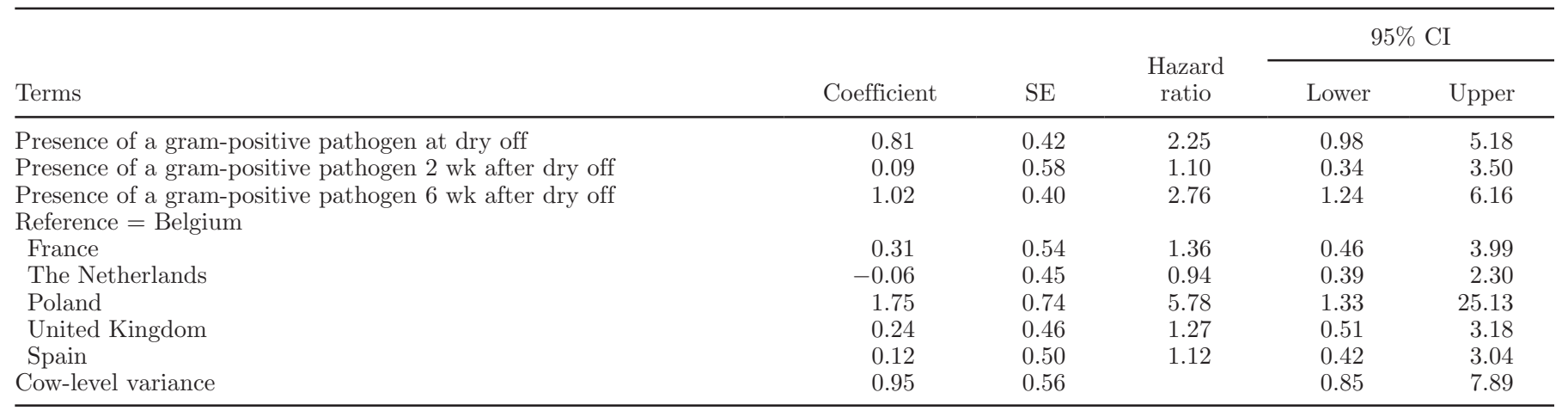


farm rather than cow effects influencing the likelihood of infection with what were predominantly environmental mastitis pathogens. This suggests that although cow factors may be influential in explaining variation within a herd, herd-level factors, and therefore perhaps overall successful dry period management, are more dependent on herd-level management factors, as has been highlighted in earlier research (Green et al., 2007, 2008).

\section{CONCLUSIONS}

This multicenter, international study confirmed the importance of the dry period in mastitis epidemiology but highlighted the variation that is seen between different farms and therefore the importance of practitioners making the effort to understand infection dynamics on individual units, rather than just assuming and extrapolating from published studies. Although this study failed to associate individual cow and quarter factors with the risk of IMI, this should not be used to downplay their importance, as it may merely be highlighting the influential effect of farm-level factors.

\section{ACKNOWLEDGMENTS}

The authors acknowledge the input of the farmers who participated in the research and the financial assistance provided by Boehringer Ingelheim (Ingelheim am Rhein, Germany).

\section{REFERENCES}

Arruda, A. G., S. Godden, P. Rapnicki, P. Gorden, L. Timms, S. S. Aly, T. W. Lehenbauer, and J. Champagne. 2013. Randomized noninferiority clinical trial evaluating 3 commercial dry cow mastitis preparations: I. Quarter-level outcomes. J. Dairy Sci. 96:4419-4435

Barreiro, J. R., C. R. Ferreira, G. B. Sanvido, M. Kostrzewa, T. Maier, B. Wegemann, V. Böttcher, M. N. Eberlin, and M. V. dos Santos. 2010. Short communication: Identification of subclinical cow mastitis pathogens in milk by matrix-assisted laser desorption/ionization time-of-flight mass spectrometry. J. Dairy Sci. 93:5661-5667.

Bradley, A. J., J. E. Breen, B. Payne, and M. J. Green. 2011. A comparison of broad spectrum and narrow spectrum dry cow therapy used alone and in combination with a teat sealant. J. Dairy Sci. 94:692-704.

Bradley, A. J., and M. J. Green. 2000. A study of the incidence and significance of intramammary enterobacterial infections acquired during the dry period. J. Dairy Sci. 83:1957-1965.

Bradley, A. J., and M. J. Green. 2001. A randomized, temporally matched, trial of the efficacy of dry cow therapy in the control of clinical coliform mastitis. J. Dairy Sci. 84:1632-1639.

Bradley, A. J., and M. J. Green. 2004. The importance of the nonlactating period in the epidemiology of intramammary infection and strategies for prevention. Vet. Clin. North Am. Food Anim. Pract. 20:547-568.

Breen, J. E., A. J. Bradley, and M. J. Green. 2009a. An investigation of quarter and cow risk factors associated with a somatic cell count greater than 199,000 cells per milliliter in UK dairy cows. J. Dairy Sci. 92:3106-3115
Breen, J. E., M. J. Green, and A. J. Bradley. 2009b. An investigation of quarter and cow risk factors associated with the occurrence of clinical mastitis in UK dairy cows. J. Dairy Sci. 92:2551-2561.

Brolund, L. 1985. Cell counts in bovine milk. Causes of variation and applicability for diagnosis of subclinical mastitis. Acta Vet. Scand. Suppl. 80:1-123.

Darlington, R. B. 1990. Multiple Tests in Regression and Linear Models. McGraw-Hill Publishing Company, Singapore.

Dingle, T. C., and S. M. Butler-Wu. 2013. MALDI-TOF mass spectrometry for microorganism identification. Clin. Lab. Med. 33:589-609.

Dingwell, R. T., K. E. Leslie, Y. H. Schukken, J. M. Sargeant, L. L. Timms, T. F. Duffield, G. P. Keefe, D. F. Kelton, K. D. Lissemore, and J. Conklin. 2004. Association of cow and quarter-level factors at drying-off with new intramammary infections during the dry period. Prev. Vet. Med. 63:75-89.

Dohoo, I. R., J. Smith, S. Andersen, D. F. Kelton, S. Godden, and Mastitis Research Workers' Conference. 2011. Diagnosing intramammary infections: Evaluation of definitions based on a single milk sample. J. Dairy Sci. 94:250-261.

Elbers, A. R., J. D. Miltenburg, D. De Lange, A. P. Crauwels, H. W Barkema, and Y. H. Schukken. 1998. Risk factors for clinical mastitis in a random sample of dairy herds from the southern part of The Netherlands. J. Dairy Sci. 81:420-426.

European Commission. 1998. Directive 98/79/EC of the European Parliament and of the Council of 27 October 1998 on in vitro diagnostic medical devices. Accessed Dec. 8, 2014. http://eur-lex. europa.eu/legal content/EN/TXT/PDF/?uri=CELEX:31998L007 $9 \&$ from $=\mathrm{EN}$.

Godden, S., P. Rapnicki, S. Stewart, J. Fetrow, A. Johnson, R. Bey, and R. Farnsworth. 2003. Effectiveness of an internal teat seal in the prevention of new intramammary infections during the dry and early-lactation periods in dairy cows when used with a dry cow intramammary antibiotic. J. Dairy Sci. 86:3899-3911.

Goldstein, H. 1995. Multilevel Statistical Models. 2nd ed. Edward Arnold, London, UK.

Green, M. J., A. J. Bradley, G. F. Medley, and W. J. Browne. 2007. Cow, farm and management factors during the dry period that determine the rate of clinical mastitis after calving. J. Dairy Sci 90:3764-3776.

Green, M. J., A. J. Bradley, G. F. Medley, and W. J. Browne. 2008. Cow, farm, and herd management factors in the dry period associated with raised somatic cell counts in early lactation. J. Dairy Sci. 91:1403-1415

Green, M. J., P. R. Burton, L. E. Green, Y. H. Schukken, A. J. Bradley, E. J. Peeler, and G. F. Medley. 2004. The use of Markov chain Monte Carlo for analysis of correlated binary data: patterns of somatic cells in milk and the risk of clinical mastitis in dairy cows. Prev. Vet. Med. 64:157-174.

Green, M. J., L. E. Green, A. J. Bradley, P. R. Burton, Y. H. Schukken, and G. F. Medley. 2005. Prevalence and associations between bacterial isolates from dry mammary glands of dairy cows. Vet. Rec. 156:71-77.

Green, M. J., L. E. Green, G. F. Medley, Y. H. Schukken, and A. J. Bradley. 2002. Influence of dry period bacterial intramammary infection on clinical mastitis in dairy cows. J. Dairy Sci. 85:25892599

Griffin, T. K., S. V. Morant, and F. H. Dodd. 1987. Diagnosing infectious subclinical mastitis in surveys or large scale experiments. The analysis and interpretation of the results of an international trial organised by the IDF mastitis expert group. Bull. Int. Dairy Fed. 211:9-24.

Huxley, J. N., M. J. Green, L. E. Green, and A. J. Bradley. 2002 Evaluation of the efficacy of an internal teat sealer during the dry period. J. Dairy Sci. 85:551-561.

IDF (International Dairy Federation). 1981. Laboratory methods for use in mastitis work. Bulletin no. 132. IDF, Brussels, Belgium.

IDF (International Dairy Federation). 1995. Enumeration of somatic cells. FIL-IDF Standard no. 148A. IDF, Brussels, Belgium.

National Mastitis Council. 1999. Laboratory Handbook on Bovine Mastitis. National Mastitis Council Inc., Madison, WI. 
Newton, H. T., M. J. Green, H. Benchaoui, V. Cracknell, T. Rowan, and A. J. Bradley. 2008. Comparison of the efficacy of cloxacillin alone and cloxacillin combined with an internal teat sealant for dry cow therapy. Vet. Rec. 162:678-684.

Pinedo, P. J., C. Fleming, and C. A. Risco. 2012. Events occurring during the previous lactation, the dry period, and peripartum as risk factors for early lactation mastitis in cows receiving 2 different intramammary dry cow therapies. J. Dairy Sci. 95:7015-7026.

Quinn, P. J., M. E. Carter, B. Markey, and G. R. Carter. 1994. Clinical Veterinary Microbiology. Wolfe, London, UK.

Rabiee, A. R., and I. J. Lean. 2013. The effect of internal teat sealant products (Teatseal and Orbeseal) on intramammary infection, clinical mastitis, and somatic cell counts in lactating dairy cows: A meta-analysis. J. Dairy Sci. 96:6915-6931.

Rasbash, J., W. J. Browne, M. Healy, B. Cameron, and C. Charlton. 2005. MLwiN Version 2.02. Multilevel Models Project, Institute of Education, London, UK.

Robert, A., H. Seegers, and N. Bareille. 2006. Incidence of intramammary infections during the dry period without or with antibiotic treatment in dairy cows-A quantitative analysis of published data. Vet. Res. 37:25-48.

Schreiner, D. A., and P. L. Ruegg. 2003. Relationship between udder and leg hygiene scores and subclinical mastitis. J. Dairy Sci. $86: 3460-3465$.
Schukken, Y. H., W. D. Kremer, and J. A. Lohuis. 1989. Escherichia coli mastitis in cattle. I. Clinical diagnosis and epidemiological aspects. Tijdschr. Diergeneeskd. 114:829-838.

Smith, K. L., D. A. Todhunter, and P. S. Schoenberger. 1985. Environmental pathogens and intramammary infection during the dry period. J. Dairy Sci. 68:402-417.

Suriyasathaporn, W., C. Heuer, E. N. Noordhuizen-Stassen, and Y. H. Schukken. 2000. Hyperketonemia and the impairment of udder defense: A review. Vet. Res. 31:397-412.

Todhunter, D. A., K. L. Smith, J. S. Hogan, and P. S. Schoenberger. 1991. Gram-negative bacterial infections of the mammary gland in cows. Am. J. Vet. Res. 52:184-188.

Wildman, E. E., G. M. Jones, P. E. Wagner, and R. L. Boman. 1982 A dairy cow body condition scoring system and its relationship to selected production characteristics. J. Dairy Sci. 65:495-501.

Williamson, J. H., M. W. Woolford, and A. M. Day. 1995. The prophylactic effect of a dry cow antibiotic against Streptococcus uberis. N. Z. Vet. J. 43:228-234.

Zadoks, R. N., H. G. Allore, H. W. Barkema, O. C. Sampimon, G. J. Wellenberg, Y. T. Grohn, and Y. H. Schukken. 2001. Cow- and quarter-level risk factors for Streptococcus uberis and Staphylococcus aureus mastitis. J. Dairy Sci. 84:2649-2663. 